\title{
Antioxidant Properties and Structure-Antioxidant Activity Relationship of Allium Species Leaves
}

\author{
Dikdik Kurnia $^{1, *(\mathbb{D}}$, Dwipa Ajiati $^{1}{ }^{(\mathbb{D}}$, Leny Heliawati $^{2}$ and Dadan Sumiarsa $^{1}$ \\ 1 Department of Chemistry, Faculty of Mathematics and Natural Science, Universitas Padjadjaran, \\ Sumedang 45363, Indonesia; dwipa20001@mail.unpad.ac.id (D.A.); dadan.sumiarsa@unpad.ac.id (D.S.) \\ 2 Study Program of Chemistry, Faculty of Mathematics and Natural Science, Universitas Pakuan, \\ Bogor 16143, Indonesia; leny_heliawati@unpak.ac.id \\ * Correspondence: dikdik.kurnia@unpad.ac.id; Tel.: +62-22-779-4391
}

Citation: Kurnia, D.; Ajiati, D.

Heliawati, L.; Sumiarsa, D.

Antioxidant Properties and StructureAntioxidant Activity Relationship of Allium Species Leaves. Molecules 2021, 26,7175. https://doi.org/10.3390/ molecules 26237175

Academic Editor: Anna Petruczynik

Received: 20 October 2021

Accepted: 15 November 2021

Published: 26 November 2021

Publisher's Note: MDPI stays neutral with regard to jurisdictional claims in published maps and institutional affiliations.

Copyright: (c) 2021 by the authors. Licensee MDPI, Basel, Switzerland. This article is an open access article distributed under the terms and conditions of the Creative Commons Attribution (CC BY) license (https:// creativecommons.org/licenses/by/ $4.0 /)$.

\begin{abstract}
Allium is a genus that is widely consumed and used as traditional medicine in several countries. This genus has two major species, namely cultivated species and wild species. Cultivated species consist of A. cepa L., A. sativum L., A. fistulosum L. and A. schoenoprasum L. and wild species consist of A. ursinum L., A. flavum L., A. scorodoprasum L., A. vineale L. and A. atroviolaceum Boiss. Several studies report that the Allium species contain secondary metabolites such as polyphenols, flavonoids and tannins and have bioactivity such as antioxidants, antibacterial, antifungal, anti-inflammatory, pancreatic $\alpha$-amylase, glucoamylase enzyme inhibitors and antiplatelets. This review summarizes some information regarding the types of Allium species (ethnobotany and ethnopharmacology), the content of compounds of Allium species leaves with various isolation methods, bioactivities, antioxidant properties and the structure-antioxidant activity relationship (SAR) of Allium compounds.
\end{abstract}

Keywords: Allium species leaves; antioxidant properties; SAR

\section{Introduction}

Antioxidants play important roles in health. They are also used to reduce disease risk and have the ability to protect the body against oxidative damages, which cause several diseases (diabetes, cancer, and neurodegenerative disorders, etc.). Antioxidants can control oxidative processes, leading to food quality descent caused by reactive oxygen species (ROS) and free radical reactions in the body [1,2].

ROS and free radicals are the main causes of oxidative stress, which can trigger several degenerative diseases such as cancer, coronary heart disease and vascular disease [3]. Based on the dangers posed by ROS and free radical reactions, it is necessary to have natural antioxidants that can prevent oxidative stress. Several studies reported that the leaves of the Allium species have good antioxidant activity [4-6].

Allium is a genus of the Liliaceae family easily found in Asia, Europe and America [7]. This genus has more than 700 species such as A. cepa L., A. satioum L., A. fistulosum L., A. schoenoprasum L. A. ursinum L., A. flavum L., A. scorodoprasum L., A. vineale L., A. atroviolaceum Boiss., A. psekemense B. Fedtsch., A. kurtzianum, A. chinense and A. rubellum and many other species from other countries [8,9]. In the last 10 years, several studies have reported that Allium contains several secondary metabolites in the bulbs, flowers and leaves [6,10-13]. Secondary metabolites are rich in health benefits because they have several bioactivities such as antioxidant, anticancer, antibacterial, antifungal, anti-inflammatory and anti-platelet [5,14-26]. Based on this, this review focused on the antioxidant activity found in the leaves of nine Allium species that have been extensively studied [27]. This review will also discuss the relationship between antioxidant activity and the structure of several compounds contained in Allium leaf extract. 


\section{Ethnobotany and Ethnopharmacology of Allium Species}

Allium cepa $\mathrm{L}$., onions, is the most cultivated plant widely used as a spice because of its distinctive taste and aroma [28]. The plant has fibrous roots and consists of 3-8 leaves. The base of the leaves is fleshy and forms bulbs that are round or elongated according to the variety [29]. A. cepa has several types of varieties, namely yellow onions, white onions, red onions and green onions [30]. This plant is easy to grow in areas with fine, rock-free and well-draining soil types. In addition, this species is known to have a hypocholesterolemic effect and can prevent heart disease [31].

Allium sativum L., garlic, is an annual plant that has been cultivated about 5000 years ago in the Middle East, is easy to grow in cold areas and has bulbs consisting of several cloves. There are $4-40$ cloves in each stem. The bulb can grow to a size of $25-70 \mathrm{~cm}$ with long, flat and folded leaves [30,31]. The flowers are greenish-white and about $3 \mathrm{~mm}$ in length $[32,33]$. Several studies reported that this plant contains compounds that have low toxicity, for example, sulfur compounds such as allicin and fructose polymers [34]. As well as A. cepa L., the plant is also reported to have heart disease-preventing effect [31].

Allium fistulosum L., known as Japanese bunching onions, welsh onions or spring onions is one of Allium species known for originating from Romania which has similarities to scallions and smells and tastes similar to A. серa L. Unlike other species, this plant does not form bulbs and has hollow leaves [35]. In Japan and China, this plant is used as a vegetable or as a traditional medicine to improve the function of internal organs and metabolism and treat several diseases such as headaches, diarrhea, stomach pains and colds $[32,36]$.

Allium schoenoprasum L., chives, is one of the important spice plants in Central Europe and is widely cultivated in several countries such as Austria, France, Germany and the Netherlands. Morphologically, this plant can adapt easily to dry and sunny habitats [37]. This species has a thin bulb, shaped like a cone with a length of $2-3 \mathrm{~cm}$ and $1 \mathrm{~cm}$ in length. The leaves are hollow and can be consumed because they have a mild onion taste. Another characteristic of this plant is that it has a soft, tube-shaped hollow stem with a diameter of $23 \mathrm{~mm}$ and purple flowers. In some countries, this species is used as traditional medicine. In Indonesia, A. schoenoprasum is used to treat hypertension. Meanwhile, in East Asia, this is used to relieve flu and lung congestion [38].

Allium ursinum L., known as bear garlic, ramsons or wild garlic, is mostly found in forest areas close to rivers. There are also those who call it forest garlic [39]. This plant can grow to a height of $50 \mathrm{~cm}$ with white flowers and bulbs of a size of less than $6 \mathrm{~cm}$ [15]. In the middle of the century, the plant is used to treat dyspepsia, cardiovascular disease, cancer, obesity and diabetes [40].

Allium flavum L., known as small yellow onion, is a species native to Southern, Central and Eastern Europe and Western Asia. This plant has leaves and bulbs that can be consumed and commonly used as a spice in several dishes such as salads, soups and stews [10]. This species has a height of about $10-60 \mathrm{~cm}$ with round elongated bulbs at the top. Other characteristics include having lanceolate-shaped leaves with stripes up to $2 \mathrm{~mm}$ long and small yellow flowers. This plant commonly grows in rocky meadows in the Mediterranean region and is used as traditional medicine because of its strong hepatoprotective, immunostimulant and antihypertensive properties [41].

Allium scorodoprasum L., wild leek, is an annual plant widely grown in the North and East Anatolia region which is commonly used as a mixture in the manufacture of cheese, yogurt and bread [42]. This species is $25-90 \mathrm{~cm}$ tall with bulbs $1-2 \mathrm{~cm}$ in diameter. In addition, this plant has leaves of 2-5 strands, each of a diameter of $2-8 \mathrm{~mm}$, and flowers are dark red and purple. Morphologically, this species is adaptable in calcareous areas, grasslands, rural areas and clay slopes. Pharmacologically, this plant is used as an antiseptic, wound healing, treating hypotension and diuretic and can prevent aging, cardiovascular disease and liver disease [43].

Allium vineale $\mathrm{L}$. known as crow garlic is a plant that is considered as a weed and originates from Eurasia. The $30-100 \mathrm{~cm}$ tall plant has membranous bulbs and linear leaves. 
The first leaf, with a length of $3-5 \mathrm{~cm}$, will become the midrib and the next leaf will cover the previous leaf blade. This species is commonly used as traditional medicine in curing several diseases such as pneumonia, ulcers, bronchitis, digestive disorders, and others [44]. $A$. vineale bulb can be used as a substitute for $A$. sativum in cooking, while the leaves are used as a salad [45].

Allium atroviolaceum Boiss. is an annual herb originating from Zagros, a region in Iran [46]. This species is used as a vegetable and also a source of vitamins [47].

\section{Isolation Methods and Compound Content of Allium Species Leaves}

\subsection{Allium cepa}

Several studies report the isolation of $A$. cepa with many methods. Samples were extracted using the solvent extraction/conventional maceration method with $70 \%$ ethanol solvent in a ratio 5:1 to the sample [7]. In another study conducted by Amabye et al., the ethanol extract was characterized by HPLC to determine the amount of phenolics [40].

From some different isolation methods, it was also reported that $A$. cepa leaves contain anthocyanin pigments [48], phenolics (catechin, cinnamic acid, ferulic acid, $p$-coumaric acid and sinapic acid) [40], tannins, saponins [49], glycosides/aglycones, quercetin 4-O- $\beta$-glycopyranoside, quercetin 3,4-O- $\beta$-diglycopyranoside, quercetin $3,7,4-O-\beta$-triglycopyranoside [7], carotenoids and glutathione $[27,50]$ (Figure 1).<smiles>[R]c1cc(-c2[o+]c3cc(O)cc(O)c3cc2O)cc([R])c1[R]</smiles>

1<smiles>COc1cc(/C=C/C(=O)O)ccc1O</smiles>

4<smiles>CC1Cc2c(O)cc(O)cc2OC1c1ccc(O)c(O)c1</smiles>

2<smiles>O=C(O)/C=C/c1ccc(O)cc1</smiles>

5<smiles>O=C(O)/C=C/c1ccccc1</smiles>

3<smiles>COc1cc(/C=C/C(=O)O)cc(OC)c1O</smiles>

6<smiles>O=C(O)c1cc(O)c(O)c(O)c1</smiles>

7<smiles>COC1CC(OC2CCC3(C)C4CCC5(C)C(C6=CC(=O)OC6)C(OC(C)=O)CC5(O)C4CCC3(C)C2)OC(C)C1O</smiles>

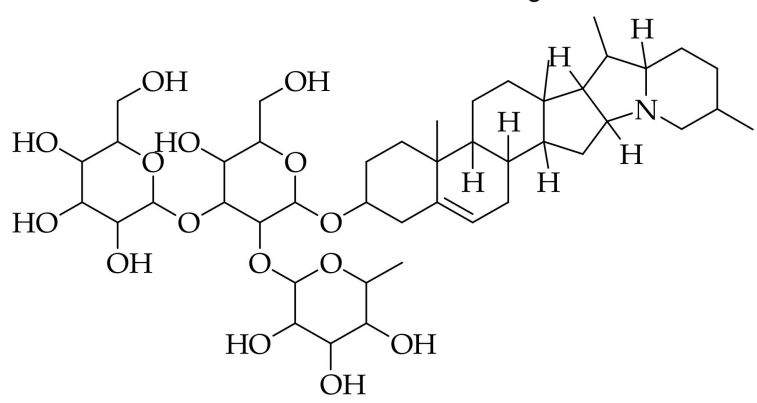

8<smiles>O=c1c(O)c(-c2ccc(OC3OC(CO)C(O)C(O)C3O)c(O)c2)oc2cc(O)cc(O)c12</smiles>

10

Figure 1. Cont. 
<smiles>O=c1c(OC2OC(CO)C(O)C(O)C2O)c(-c2ccc(OC3OC(CO)C(O)C(O)C3O)c(O)c2)oc2cc(O)cc(O)c12</smiles>

11<smiles>CC1=C(/C=C/C(C)=C/C=C/C(C)=C/C=C/C=C(C)/C=C/C=C(C)/C=C/C2=C(C)CCCC2(C)C)C(C)(C)CCC1</smiles>

13<smiles>O=c1c(OC2OC(CO)C(O)C(O)C2O)c(-c2ccc(OC3OC(CO)C(O)C(O)C3O)c(O)c2)oc2cc(OC3OC(CO)C(O)C(O)C3O)cc(O)c12</smiles>

12<smiles>NC(CCC(=O)NC(CS)C(=O)NCC(=O)O)C(=O)O</smiles>

14

Figure 1. Compounds obtained from A. cepa leaf extract using different isolation methods. (1) anthocyanin [48]; (2) catechin; (3) cinnamic acid; (4) ferulic acid; (5) p-coumaric acid; (6) sinapic acid [40]; (7) tannin; (8) saponin [49]; (9) glycoside; (10) quercetin 4-O- $\beta$-glycopyranoside; (11) quercetin 3,4-O- $\beta$-diglycopyranoside; (12) quercetin 3,7,4-O- $\beta$ triglycopyranoside [7]; (13) $\beta$-caroten; (14) glutathione [27].

\subsection{Allium sativum}

Studies concerning $A$. sativum also use several isolation methods. Sample residue was extracted using petroleum ether, chloroform and ethyl acetate. Then, the chloroform extract was analyzed using silica gel column chromatography (60-120 mesh) with mobile phase $\mathrm{CHCl}_{3}-\mathrm{MeOH}(90: 10 ; 80: 20 ; 70: 30 ; 50: 50)$ and guided by TLC with mobile phase $\mathrm{CHCl}_{3}-\mathrm{MeOH}(90: 10)$ and iodine vapor was used as a detecting agent. In the $\mathrm{CHCl}_{3}-\mathrm{MeOH}$ fraction (70:30), a single stain of oleanolic acid compound was obtained [49]. Isolation was carried out to obtain methanol, chloroform and aqueous extracts using the conventional maceration method [51]. In addition, five new compounds were obtained in the form of cyclic organosulfur compounds. The five compounds were successfully isolated from the acetone extract, which was partitioned with the EtOAc- $\mathrm{H}_{2} \mathrm{O}$ mobile phase (1:1) and separated by normal phase silica gel column chromatography with $\mathrm{CHCl}_{3}-\mathrm{MeOH}$ mobile phase $(1: 0 ; 100: 1 ; 50: 1 ; 30: 1 ; 10: 1 ; 0: 1)$ to produce nine fractions and followed by reversephase silica gel column chromatography with $\mathrm{MeOH}-\mathrm{H}_{2} \mathrm{O}(2: 8 ; 4: 6 ; 6: 4 ; 8: 2 ; 1: 0)$ as mobile phase until thirteen fractions were obtained. Subsequently, the thirteen fractions were purified by HPLC to obtain five pure compounds [52].

Several studies report that $A$. sativum leaves contain a triterpene compound, namely oleanolic acid [53]. The research conducted by Wilson et al. reported that the leaf extract of A. sativum contained terpenoids in the methanol extract, glycosides in the chloroform extract and saponins, terpenoids and glycosides in the aqueous extract [51]. In addition, phytochemical tests on aqueous extracts showed the presence of flavonoids, alkaloids, steroids, triterpenes [54], S-allyl-L-cysteine, glutamyl-S-allyl-L-cysteine, S-allyl-L-cysteine sulfoxide (allin) $[55,56]$, foliogarlic disulfane $A_{1}$, foliogarlic disulfane $A_{2}$, foliogarlic disulfane $A_{3}$, foliogarlic trisulfane $A_{1}$, foliogarlic trisulfane $A_{2}$ [52], quercetin 3-O- $\beta$-D-glucopyranoside (isoquercitrin), quercetin 3-O- $\beta$-D-xylopyranoside (reynoutrin), kaempferol 3-O- $\beta$-D-glucopyranoside (astragalin) and isorhamnetin 3-O- $\beta$-D-glucopyranoside [57] (Figure 2). 
<smiles>C=CCSCC([NH])C(=O)O</smiles>

15<smiles>C=CCSSC(O)[C@H](C)[C@@]1(O)C(=O)O[C@H]2[C@@H](O)CO[C@]21O</smiles>

18<smiles>C=CCSSS[C@H]1O[C@@]2(OC[C@@H](O)C2(O)O)C(=O)O[C@H]1[C@H](C)O</smiles>

21<smiles></smiles>

24<smiles>C=CCSCC(NC(=O)CCC([NH-])C(=O)O)C(=O)O</smiles>

16

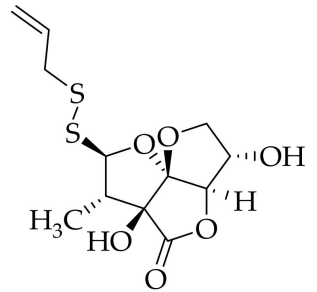

19<smiles>C=CCSSS[C@H]1O[C@@]2(O)C([C@H](O)CO)OC(=O)[C@]2(O)[C@H]1C</smiles>

22<smiles>CC(=O)c1c(OC2OC(CO)C(O)C(O)C2O)oc2cc(O)cc(O)c2c1=O</smiles>

25<smiles>C=CCS(=O)CC(N)C(=O)O</smiles>

17<smiles>C=CCSS[C@H]1O[C@@]2(O)[C@@H](O)CO[C@H]2C1(O)C(C)C</smiles>

20<smiles></smiles>

23<smiles>COc1cc(-c2oc3cc(O)cc(O)c3c(=O)c2OC2OC(CO)C(O)C(O)C2O)ccc1O</smiles>

26

Figure 2. Compounds obtained from A. sativum leaf extract using different isolation methods. (15) $S$ allyl-L-cysteine; (16) $\gamma$-glutamyl-S-allyl-L-cysteine; (17) $S$-allyl-L-cysteine sulfoxide [55]; (18) foliogarlic disulfane $A_{1} ;(19)$ foliogarlic disulfane $A_{2} ;(20)$ foliogarlic disulfane $A_{3} ;(21)$ foliogarlic trisulfane $\mathrm{A}_{1}$; (22) foliogarlic trisulfane $\mathrm{A}_{2}$ [52]; (23) quercetin 3-O- $\beta$-D-glucopyranoside; (24) quercetin 3-O- $\beta$-D-xylopyranoside; (25) kaempferol 3-O- $\beta$-D-glucopyranoside; (26) isorhamnetin 3-O- $\beta$-Dglucopyranoside [57].

\subsection{Allium fistulosum}

Based on research conducted by Fukaya et al., seven compounds were isolated using a simple maceration extraction method with acetone as a solvent. Furthermore, the extract was partitioned with EtOAc- $\mathrm{H}_{2} \mathrm{O}(1: 1)$ to obtain the EtOAc fraction then separated using normal phase silica gel column chromatography $\left[\mathrm{CHCl}_{3}-\mathrm{MeOH}(1: 0 ; 200: 1 ; 100: 1 ; 50: 1 ; 0: 1)\right]$; [hexane-acetone $(1: 0 ; 6: 1 ; 4: 1 ; 3: 1 ; 2: 1 ; 0: 1)]$ and reverse phase $\left[\mathrm{MeOH}-\mathrm{H}_{2} \mathrm{O}(6: 4 ; 7: 3 ; 8: 2\right.$; 9:1; 1:0)]. The last step is purification using HPLC [58]. There is no difference from other methods in the isolation of apigenin compounds carried out by Immaculate V. et al. using the TLC method and purified by HPLC. Aqueous extracts were analyzed by GC-MS [59]. The acetone extract was partitioned with EtOAc- $\mathrm{H}_{2} \mathrm{O}$ as a solvent and separated by silica gel column chromatography with $\mathrm{CHCl}_{3}-\mathrm{MeOH}(100: 1)$ as mobile phase to obtain five fractions. Furthermore, fraction 3 was purified again by silica gel column chromatography with $n$-hexane-acetone (6:1) as mobile phase [60]. 
Several isolation methods of several studies reported that $A$. fistulosum leaf extract contains flavonoids (myricetin, quercetin, rutin, kaempferol, naringenin and hesperetin), polyphenols (benzoic acid, salicylic acid, ferulic acid, caffeine, $p$-coumaric acid, coumarin, vanillic acid, gallic acid and cinnamic acid) [61], kujounin $A_{3}$, kujounin $B_{1}$, kujounin $B_{2}$, kujounin $B_{3}$, allium sulfoxide $A_{2}$, allium sulfoxide $A_{3}$, kujounin $A_{1}$ [58], apigenin (4',5,7-trihydroxy-flavone) [35], dichloroacetic acid, 1-buten-3-yne, 1-chloro-, (Z)-,-pinene, D-limonene, thymol [59], onionin $\mathrm{A}_{1}$, onionin $\mathrm{A}_{2}$ and onionin $\mathrm{A}_{3}$ [60] (Figure 3).<smiles>O=c1c(O)c(-c2cc(O)c(O)c(O)c2)oc2cc(O)cc(O)c12</smiles>

27<smiles>O=c1c(O)c(-c2ccc(O)cc2)oc2cc(O)cc(O)c12</smiles>

30<smiles>O=C(O)c1ccccc1</smiles>

33<smiles>Cn1c(=O)c2c(ncn2C)n(C)c1=O</smiles>

36<smiles>O=C(O)c1cc(O)c(O)c(O)c1</smiles>

40<smiles>CCCSS[C@H](O)[C@@H](C)[C@@]12OC[C@@H](O)[C@H]1OC(=O)[C@H]2O</smiles>

43<smiles>O=c1c(O)c(-c2ccc(O)c(O)c2)oc2cc(O)cc(O)c12</smiles><smiles>CC1OC(OCC2OC(Oc3c(-c4ccc(O)c(O)c4)oc4cc(O)cc(O)c4c3=O)C(O)C(O)C2O)C(O)C(O)C1O</smiles>

28<smiles>O=C1CC(c2ccc(O)cc2)Oc2cc(O)cc(O)c21</smiles>

31<smiles>O=C(O)c1ccccc1O</smiles>

34<smiles>O=C(O)/C=C/c1ccc(O)cc1</smiles>

37<smiles>O=C(O)/C=C/c1ccccc1</smiles>

41<smiles>CCCSS[C@H]1O[C@@]23C(OC(=O)[C@H]2O)[C@H](O)CO[C@]13O</smiles>

44<smiles>COc1ccc(C2CC(=O)c3c(O)cc(O)cc3O2)cc1O</smiles>

32<smiles>COc1cc(/C=C/C(=O)O)ccc1O</smiles>

35<smiles>COc1cc(C(=O)O)ccc1O</smiles>

38

39

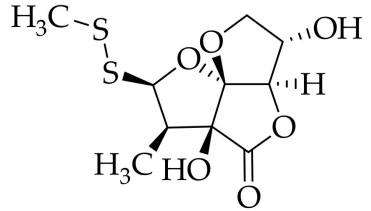

42<smiles>CCCSS[C@H]1O[C@@]23OC[C@@H](O)C2OC(=O)[C@]3(O)[C@H]1C</smiles>

45

Figure 3. Cont. 
<smiles>CO[C@H]1SC([S+](C)[O-])C(C)C1C</smiles>

46<smiles></smiles>

494<smiles>C=C1CCC2CC1C2(C)C</smiles>

53<smiles>C/C=C/[C@H]1C(C)C(C)[C@@H](SO)[S+]1=O</smiles>

56<smiles>CO[C@H]1SC([S+](C)=O)[C@@H](C)[C@@H]1C</smiles>

47<smiles>O=C(O)C(Cl)Cl</smiles>

50<smiles>C=C(C)C1CC=C(C)CC1</smiles>

54<smiles>C/C=C/[C@H]1[C@@H](C)C(C)[C@@H](SO)[S+]1=O</smiles>

57

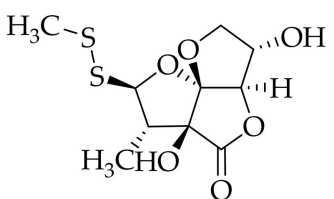

48<smiles>C#CC=C</smiles><smiles>Cc1ccc(C(C)C)c(O)c1</smiles>

55<smiles>C/C=C/[C@H]1[C@@H](C)C(C)[C@@H](SO)[S+]1[O-]</smiles>

58

Figure 3. Compounds obtained from A. fistulosum leaf extract using different isolation methods. (27) myricetin; (28) quercetin; (29) rutin; (30) kaempferol; (31) naringenin; (32) hesperetin; (33) benzoic acid; (34) salicylic acid; (35) ferulic acid; (36) caffeine; (37) $p$-coumaric acid; (38) coumarin; (39) vanillic acid; (40) gallic acid; (41) cinnamic acid [61]; (42) kujounin $\mathrm{A}_{3}$; (43) kujounin $\mathrm{B}_{1}$; (44) kujounin $\mathrm{B}_{2}$; (45) kujounin $\mathrm{B}_{3}$; (46) allium sulfoxide $A_{2}$; (47) allium sulfoxide $A_{3}$; (48) kujounin $A_{1}$ [59]; (49) apigenin [35]; (50) dichloroacetic acid; (51) 1-buten-3-yne; (52) $\alpha$-pinene; (53) $\beta$-pinene; (54) Dlimonene; (55) thymol [59]; (56) onionin $\mathrm{A}_{1}$; (57) onionin $\mathrm{A}_{2}$; (58) onionin $\mathrm{A}_{3}$ [60].

\subsection{Allium schoenoprasum}

In a study conducted by Dominguez et al., A. schoenoprasum leaves were extracted using conventional maceration with an ethanol solvent [62]. In some studies, the sample was also extracted using a hydrodistillation method and analyzed by GC-MS [63]. The extract was partitioned with EtOAc- $\mathrm{H}_{2} \mathrm{O}(1: 1)$ and isolated by normal phase silica gel column chromatography with $\mathrm{CHCl}_{3}-\mathrm{MeOH}(1: 0 ; 200: 1 ; 100: 1 ; 50: 1 ; 0: 1)$ as mobile phase, then, fraction 2 was isolated using reverse-phase silica gel column chromatography with $\mathrm{MeOH}-\mathrm{H}_{2} \mathrm{O}(6: 4 ; 7: 3 ; 8: 2 ; 9: 1 ; 1: 0)$ as mobile phase and purified by $\mathrm{HPLC}$ with $\mathrm{H}_{2} \mathrm{O}-\mathrm{MeCN}$ (60:40) as mobile phase [58]. In addition, the Folin-Ciocalteu method was also used to analyze the phytochemical content [64].

A. schoenoprasum leaf extract from some studies with different methods reported that these contain bis-(2-sulfhydryethyl)-disulfide, 2,4,5-trithiahexane, tris-(methylthio)methane [63], quercetin, kaempferol, myricetin, catechin, rutin, chlorogenic acid, $p$-coumaric acid, ferulic acid, caffeic acid [62,65], folionin $A_{1}$, folionin $A_{2}$, folionin B [66], sitosterol, stigmasterol, campesterol, cholesterol, free fatty acid, monoacylglycerin, diacylglycerin, triacylglycerin, linoleic acid, palmitic acid, spirostanols (deltonin, saponin A), furostanols (deltoside, protodioscin) [67] and I-ketose [68] (Figure 4). 


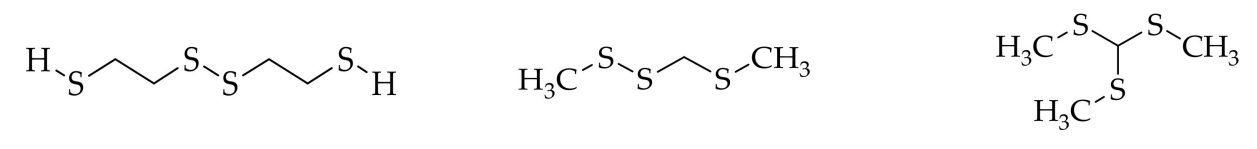

59<smiles>O=c1c(O)c(-c2ccc(O)c(O)c2)oc2cc(O)cc(O)c12</smiles>

62<smiles>Oc1cc(O)c2c(c1)OC(c1ccc(O)c(O)c1)C(O)C2</smiles>

65<smiles>O=C(O)/C=C/c1ccc(O)cc1</smiles>

68<smiles>C/C=C/[S+]([O-])C1C(C)C(C)C(SSC)[S+]1=O</smiles>

71

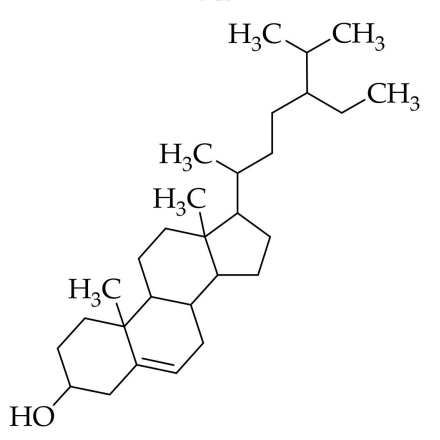

74
60<smiles>O=c1c(O)c(-c2ccc(O)cc2)oc2cc(O)cc(O)c12</smiles>

63<smiles>CC1OC(OCC2OC(Oc3c(-c4ccc(O)c(O)c4)oc4cc(O)cc(O)c4c3=O)C(O)C(O)C2O)C(O)C(O)C1O</smiles>

66<smiles>COc1cc(/C=C/C(=O)O)ccc1O</smiles>

69<smiles>C/C=C/[Si]([O-])C1C(C)C(C)C(SSC)[S+]1=O</smiles>

72

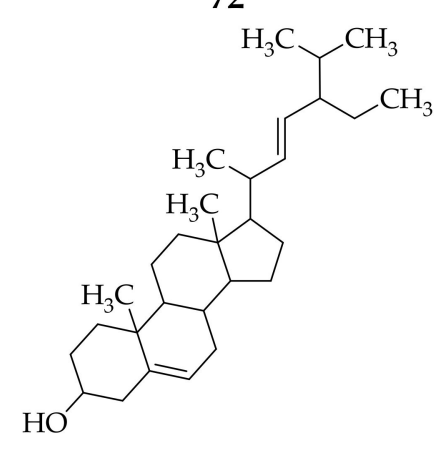

75<smiles>O=c1c(O)c(-c2cc(O)c(O)c(O)c2)oc2cc(O)cc(O)c12</smiles>

34<smiles>O=C(/C=C/c1ccc(O)c(O)c1)OC1CC(O)(C(=O)O)CC(O)C1O</smiles>

67<smiles>O=C(O)/C=C/c1ccc(O)c(O)c1</smiles>

70<smiles>C/C=C/[Si](=O)C1C(C)C(C)C(SCCC)[Si]1[O-]</smiles>

73

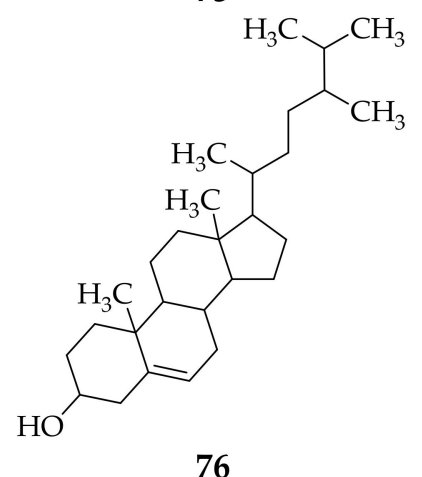

Figure 4. Cont. 


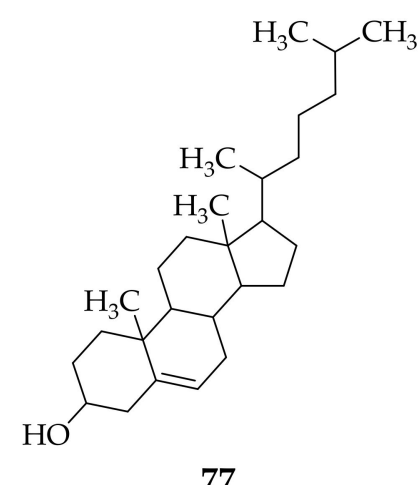

$\underbrace{77}_{\pi_{O}^{R}}$

80<smiles>CCCCCCCCCCCCC(=O)O</smiles><smiles>[R]C(=O)OC(CO)CO</smiles>

78<smiles>[R]C(=O)OCC(COC([R])=O)OC([R])=O</smiles>

81<smiles>CCCCC/C=C\C/C=C\CCCCCCCC(=O)O</smiles>

82<smiles>CCCCCCCCCCCCCCCCC(=O)O</smiles>

83<smiles>CC1C2OC3(CCCCO3)OC2CC2C3CCC4CCCC(O)C4(CCC13C)C2C</smiles>

84<smiles>CC1CCC2(OC1)OC1CC3C4CC=C5CC(OC6OC(CO)C(OC7OC(CO)C(O)C(O)C7O)C(O)C6OC6OC(C)C(O)C(O)C6O)CCC5(C)C4CCC3(C)C1C2C</smiles>

85

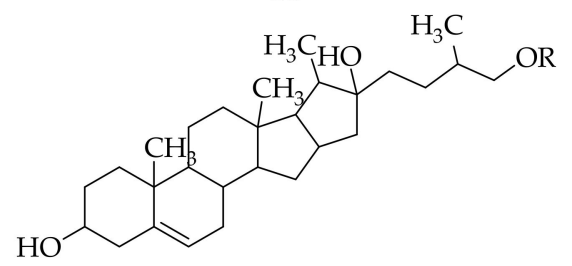

87

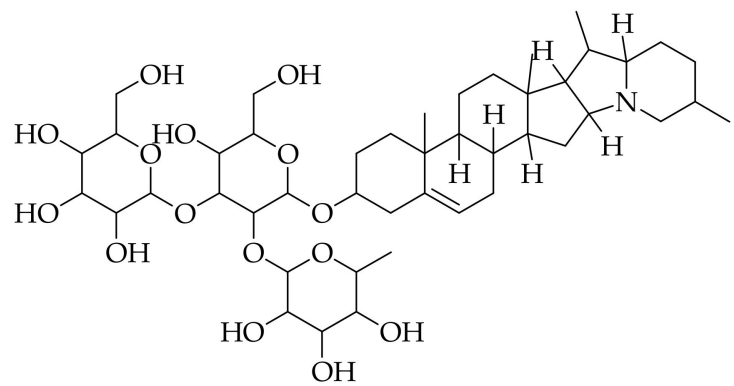

86<smiles>O=C(CO)CO</smiles>

Figure 4. Cont. 


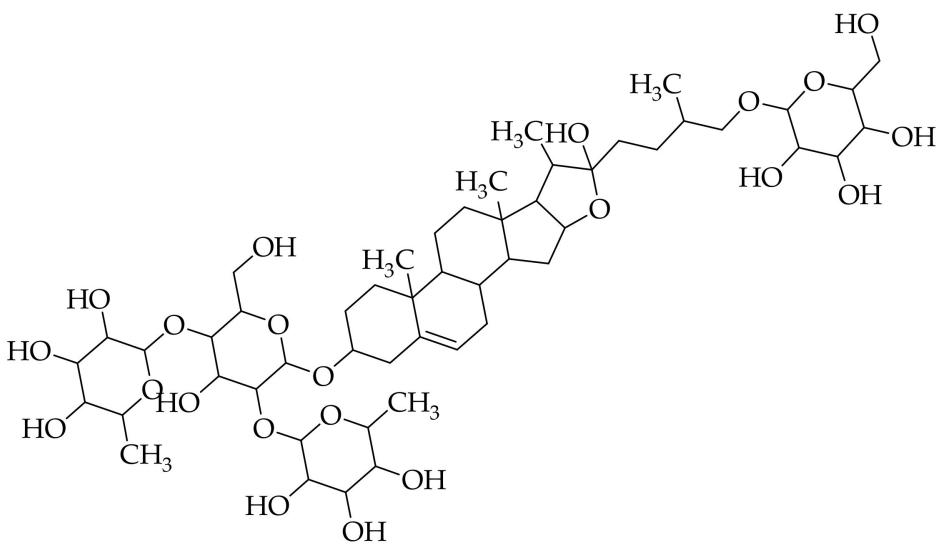

89

Figure 4. Compounds obtained from A. schoenoprasum leaf extract using different isolation methods. (59) bis(2-sulfhydryethyl)-disulfide; (60) 2,4,5-trithiahexane; (61) tris(methylthio)-methane; (62) quercetin; (63) kaempferol; (64) myricetin; (65) catechin; (66) rutin; (67) chlorogenic acid; (68) $p$-coumaric acid; (69) ferulic acid; (70) caffeic acid [61,63];

(71) folionin $\mathrm{A}_{1}$; (72) folionin $\mathrm{A}_{2}$; (73) folionin $\mathrm{B}$ [66]; (74) sitosterol; (75) stigmasterol; (76) campesterol; (77) cholesterol;

(78) free fatty acid; (79) monoacylglycerin; (80) diacylglycerin; (81) triacylglycerin; (82) linoleic acid; (83) palmitic acid;

(84) spirostanols; (85) deltonin; (86) saponin; (87) furostanols [67]; (88) I-ketose [68]; (89) protodioscin [67].

\subsection{Allium ursinum}

Studies concerning A. ursinum also use several isolation methods. In a study conducted by Barla et al., a sample was extracted with an aqueous-ethanol solvent for $2 \mathrm{~h}$ at $80{ }^{\circ} \mathrm{C}$ to obtain a powdered extract [69]. In another study, a sample was extracted using two maceration methods, namely by water infusion and water decoction. Then, the determination of the amount of phenolic content was conducted by the colorimetric assays [70].

From some different isolation methods of several studies, it was reported that $A$. ursinum extract contains $p$-coumaric acid, ferulic acid, kaempferol, kaempferol-3-O-glycoside, ursolic acid, quercetin, phenol compound [7,10,71], allicin [21], malondialdehyde (MDA), carotenoids [27,50,68], kaempferol-3,7-di-O- $\beta$-D-glucopyranoside, kaempferol-(acetylhexoside)-hexoside, acetylkaempferol-deoxyhexose [71], propylene sulfide, dimethyldisulfide, dimethylthiophene, (E)-methyl-2-propyl disulfide, (Z)-methyl-2-propenyl disulfide, dimethyl trisulfide, di-2propenyl disulfide, 2-vinyl-1,3-dithiane, (E)-propenyl propyl disulfide, (Z)-propenyl propyl disulfide, methyl-2-propenyl trisulfide, 3,4-dihydro-3-vinyl-1,2-dithiine, 2-vinyl-4H-1,3dithiine, dimethyl tetrasulfide, (E)-di-2-propenyl trisulfide, (Z)-di-2-propenyl trisulfide, di-2-propyl trisulfide, di-2-propenyl tetrasulfide [72], inulin, nystose, and I-ketose [68] (Figure 5).<smiles>O=C(O)/C=C/c1ccc(O)cc1</smiles>

90<smiles>COc1cc(/C=C/C(=O)O)ccc1O</smiles>

91<smiles>O=c1c(O)c(-c2ccc(O)cc2)oc2cc(O)cc(O)c12</smiles>

92

Figure 5. Cont. 
<smiles>O=c1c(OC2OC(CO)C(O)C(O)C2O)c(-c2ccc(O)cc2)oc2cc(O)cc(O)c12</smiles>

93<smiles>C=CCSS(=O)CC=C</smiles>

96

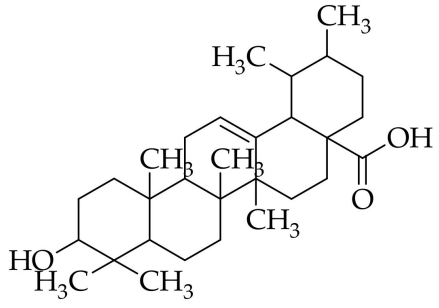

94<smiles>O=CCC=O</smiles>

97<smiles>O=c1c(O)c(-c2ccc(O)c(O)c2)oc2cc(O)cc(O)c12</smiles>

95

989<smiles>O=c1c(OC2CC(CO)C(O)C(O)C2O)c(-c2ccc(O)cc2)oc2cc(OC3OC(CO)C(O)C(O)C3O)cc(O)c12</smiles>

99<smiles>CCCSSC</smiles>

103<smiles>C=CC1SCCCS1</smiles>

107<smiles>C=CC1CC=CSS1</smiles>

111<smiles>C=CCSSSSCC=C</smiles>

115<smiles>CCOC1(OC2(CO)OC(CO)C(O)C2O)OC(CO)(CO)C(OC2OC(CO)C(O)C(O)C2O)C1(CO)OC1C(O)C(O)C(O)C1O</smiles>

118<smiles>CC1CS1</smiles>

100<smiles>C/C=C/SSC</smiles><smiles>CC=CSSCCC</smiles>

108<smiles>C=CC1SC=CCS1</smiles>

112<smiles>CCCSSSCCC</smiles>

116<smiles>CSSC</smiles>

101 ${ }^{-S}{ }_{S^{-}}{ }^{-S} \backslash$

105<smiles>C=CCSSCC=C</smiles><smiles>C=CCSSSC</smiles>

109

110<smiles>CSSSSC</smiles>

113<smiles>C=CCSSSCC=C</smiles>

114<smiles>[Z17][SH](SCC=C)SSCC=C</smiles><smiles>OCC1OC(OC2(COC3(COC4(CO)OC(CO)C(O)C4O)OC(CO)C(O)C3O)OC(CO)C(O)C2O)C(O)C(O)C1O</smiles>

119

Figure 5. Compounds obtained from A. ursinum leaf extract using different isolation methods. (90) $p$-coumaric acid; (91) ferulic acid; (92) kaempferol; (93) kaempferol-3-O-glycoside; (94) ursolic acid; (95) quercetin [39]; (96) allicin [21]; (97) malondialdehyde; (98) $\beta$-caroten; (99) kaempferol-3,7-di-O- $\beta$-D-glucopyranoside [71]; (100) propylene sulfide; (101) dimethyldisulfide; (102) 2,4-dimethylthiophene; (103) (E)-methyl-2-propyl disulfide; (104) (Z)-methyl-2-propenyl disulfide; (105) dimethyl trisulfide; (106) di-2-propenyl disulfide; (107) 2-vinyl-1,3-dithiane; (108) (E)-propenyl propyl disulfide; (109) (Z)-propenyl propyl disulfide; (110) methyl-2-propenyl trisulfide; (111) 3,4-dihydro-3-vinyl-1,2-dithiine; (112) 2-vinyl-4H-1,3-dithiine; (113) dimethyl tetrasulfide; (114) (E)-di-2-propenyl trisulfide; (115) (Z)-di-2-propenyl trisulfide; (116) di-2-propyl trisulfide; (117) di-2-propenyl tetrasulfide [72]; (118) inulin; (119) nystose; (120) I-ketose [68]. 


\subsection{Allium flavum}

Rezgui et al. also conducted research concerning A. flavum. The study conducted refluxing samples two times for $1 \mathrm{~h}$ with $\mathrm{MeOH}-\mathrm{H}_{2} \mathrm{O}$ (7:3) [11]. The solvent was evaporated and then VLC (silica gel RP-18, MeOH- $\mathrm{H}_{2} \mathrm{O} 50: 50$ ) was conducted to produce several fractions to separate using CC (Sephadex $\mathrm{LH}-20, \mathrm{MeOH}$ ). The last step was the MPLC method (RP-18 silica gel, $\mathrm{MeOH} / \mathrm{H}_{2} \mathrm{O}$ gradient $40-100 \%$ ) to obtain pure compounds [11]. In addition, in another study, samples were suspended in $5 \mathrm{~mL} 1 \mathrm{~mol} / 1 \mathrm{~K}_{2} \mathrm{HPO}_{4}$ with $\mathrm{pH}$ 7.0 and centrifuged for $10 \mathrm{~min}$ to obtain an aliquot of the supernatant, which will be used in the SOD activity test [27].

The results of several studies with different methods reported that $A$. flavum leaves contains three new compounds of spirostane-type glycosides, namely $(20 S, 25 R)-2 \alpha$-hydroxyspirost-5-

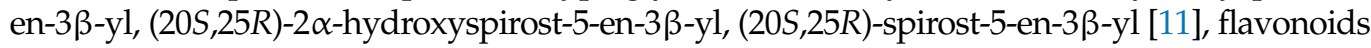
and carotenoids [27] (Figure 6).

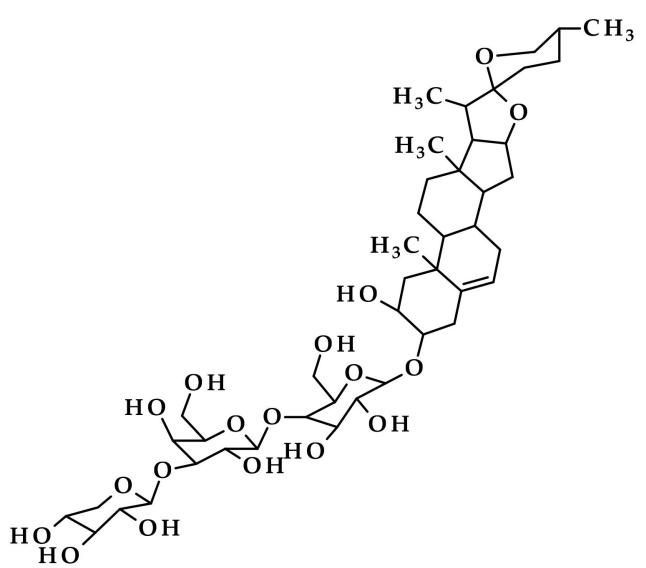

121

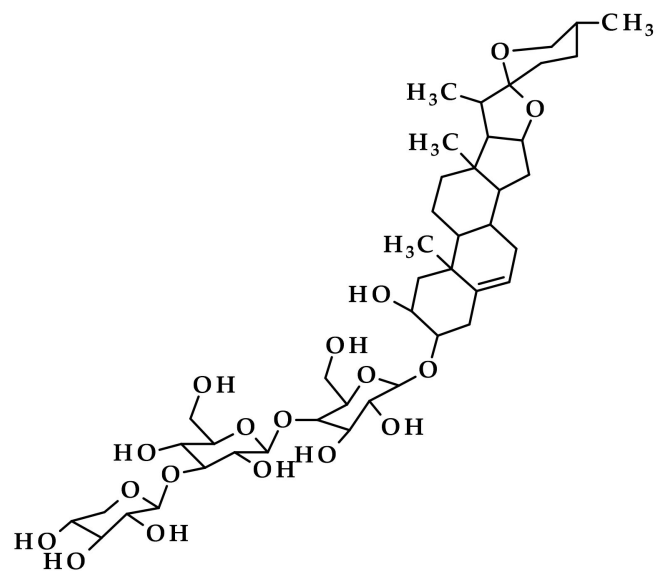

122

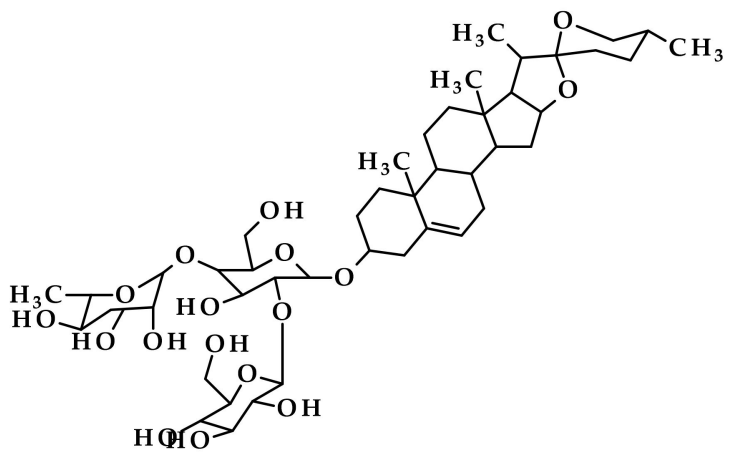

123

Figure 6. Three new compounds of spirostane-type glycosides obtained from A. flavum leaf extract: (121) (20S,25R)-2 $\alpha$-hydroxyspirost-5-en-3 $\beta$-yl; (122) $(20 S, 25 R)-2 \alpha$-hydroxyspirost-5-en-3 $\beta$-yl; (123) $(20 S, 25 R)$-spirost-5-en-3 $\beta$-yl [11].

\subsection{Allium scorodoprasum}

Prior to the antioxidant activity test, Tasci et al. first performed a sample extraction with $80 \%$ using an ultrasonic bath [12].

A. scorodoprasum leave contains flavonoid and carotenoid compounds [27]. In addition, in research conducted by Tasci et al., the organosulfur compound obtained was allicin [12] (Figure 7). 


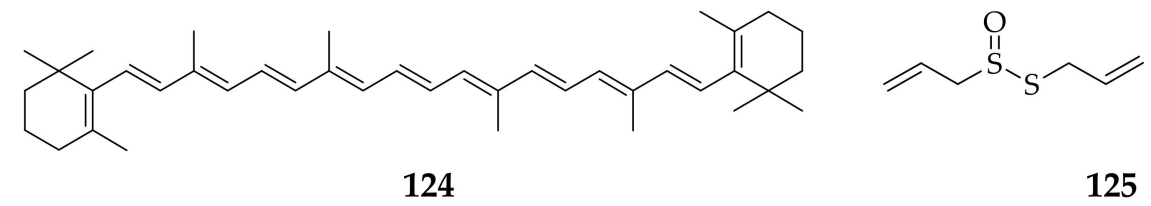

Figure 7. Compounds obtained from A. scorodoprasum leaf extract using ultrasonic bath: (124) $\beta$ caroten [27]; (125) allicin [12].

\subsection{Allium vineale}

Several methods were used to isolate compounds from $A$. vineale. One of the methods used was a sample hydrodistilled first for $4 \mathrm{~h}$ and extracted with $\mathrm{CH}_{2} \mathrm{Cl}_{2}$. The filtrate was obtained and then evaporated to remove the solvent to obtain essential oils that have a sharp odor [45]. In other research, a sample $A$. vineale was first boiled using distilled water before being extracted with ethyl acetate and a concentrated organic layer. The extract obtained was then partitioned using silica gel chromatography with hexane, ethyl acetate and methanol as mobile phases to obtain twenty-five fractions [16].

Based on the previous studies using different isolation methods of this species, it contains 2-furaldehyde, (2E)-hexenal, (3Z)-hexenol, 2,4-dimethylthiophene, allyl methyl disulfide, methyl (Z)-1-propenyl disulfide, methyl (E)-1-propenyl disulfide, benzaldehyde, dimethyl trisulfide, diallyl disulfide, allyl (Z)-1-propenyl disulfide, allyl (E)-1-propenyl disulfide, 1-propenyl propyl disulfide, methyl (methylthio)methyl disulfide, allyl methyl trisulfide, 4-methyl-1,2,3-trithiolane, methyl propyl trisulfide, methyl (Z)-1-propenyl trisulfide, methyl (E)-1-propenyl trisulfide, dimethyl tetrasulfide, allyl (methylthio)methyl disulfide, diallyl trisulfide, allyl (Z)-1-propenyl trisulfide, $p$-vinylguaiacol, allyl propyl trisulfide, 5-methyl-1,2,3,4-tetrathiane, methyl (methylthio)methyl trisulfide, allyl methyl tetrasulfide, allyl (methylthio)methyl trisulfide, 4-methyl-1,2,3,5,6-pentathiepane [45], chrysoeriol, chrysoeriol-7-O[2 00-O-E-feruloyl]- $\beta$-D-glucoside and isorhamnetin-3-O- $\beta$-Dglucoside [16] (Figure 8).<smiles>O=Cc1ccco1</smiles>

126<smiles>C=CCSSC</smiles>

130<smiles>CSSSC</smiles>

134<smiles>C/C=C\SSCCC</smiles>

138<smiles>CCC/C=C/C=O</smiles>

127<smiles>C/C=C\SSC</smiles>

131<smiles>C=CCSSCC=C</smiles>

135<smiles>CSCSSC</smiles>

139<smiles>CCCC/C=C\O</smiles>

128<smiles>CC=CSSC</smiles>

132<smiles>C=CCSS/C=C\C</smiles>

136<smiles>C=CCSSSC</smiles>

140<smiles>Cc1csc(C)c1</smiles>

129<smiles>O=Cc1ccccc1</smiles>

133<smiles>C=CCSSC=CC</smiles>

137

141

Figure 8. Cont. 
<smiles>CCCSSSC</smiles>

142<smiles>C=CC(SC)SSC</smiles>

146<smiles>C=CCSSSCCC</smiles>

150<smiles>C=CC(SC)SSSC</smiles><smiles>C/C=C\SSSC</smiles>

143<smiles>CC=CSSSC</smiles>

144<smiles>CSSSSC</smiles>

145<smiles>C=CCSSSCC=C</smiles>

147<smiles>C=CCSSS/C=C\C</smiles>

148<smiles>C=Cc1ccc(O)c(OC)c1</smiles>

149<smiles>CC1CSSSS1</smiles>

151<smiles>CSCSSSC</smiles>

152<smiles>CC1SSCSSS1</smiles>

155<smiles>COc1cc(-c2cc(=O)c3c(O)cc(O)cc3o2)ccc1O</smiles>

156<smiles>COc1cc(-c2oc3cc(O)cc(O)c3c(=O)c2OC2OC(CO)C(O)C(O)C2O)ccc1O</smiles><smiles>COc1cc(-c2cc(=O)c3c(O)cc(OC4OC(CO)C(O)C(O)C4O)cc3o2)ccc1O</smiles>

157

158

Figure 8. Compounds obtained from $A$. vineale leaf extract using different isolation methods. (126) 2 furaldehyde; (127) (2E)-hexenal; (128) (3Z)-hexenol; (129) 2,4-dimethylthiophene; (130) allyl methyl disulfide; (131) methyl (Z)-1-propenyl disulfide; (132) methyl (E)-1-propenyl disulfide; (133) benzaldehyde; (134) dimethyl trisulfide; (135) diallyl disulfide; (136) allyl (Z)-1-propenyl disulfide; (137) allyl (E)-1-propenyl disulfide; (138) 1-propenyl propyl disulfide; (139) methyl (methylthio)methyl disulfide; (140) allyl methyl trisulfide; (141) 4-methyl-1,2,3-trithiolane; (142) methyl propyl trisulfide; (143) methyl (Z)-1-propenyl trisulfide; (144) methyl (E)-1-propenyl trisulfide; (145) dimethyl tetrasulfide; (146) allyl (methylthio)methyl disulfide; (147) diallyl trisulfide; (148) allyl (Z)-1-propenyl trisulfide; (149) $p$-vinylguaiacol; (150) allyl propyl trisulfide; (151) 5-methyl-1,2,3,4-tetrathiane; (152) methyl (methylthio)methyl trisulfide; (153) allyl methyl tetrasulfide; (154) allyl (methylthio)methyl trisulfide; (155) 4-methyl-1,2,3,5,6-pentathiepane [45]; (156) chrysoeriol; (157) chrysoeriol-7-O[200-O-E-feruloyl]$\beta$-D-glucoside; (158) isorhamnetin-3-O- $\beta$-D-glucoside [16].

\subsection{Allium atroviolaceum}

Based on the research method conducted by Sebtosheikh et al., samples were cut into small pieces and extracted by hydrodistillation using a Clevenger-a type of apparatus for $4 \mathrm{~h}$. The extract obtained was then evaporated using anhydrous sodium sulfate and stored at $4{ }^{\circ} \mathrm{C}$. Then, the dry extract was analyzed using GC-MS [73,74]. In another research, dry samples were extracted by maceration with $\mathrm{H}_{2} \mathrm{O}$ and $70 \%$ ethanol for $48 \mathrm{~h}$. The extract was filtered and evaporated to remove the solvent to obtain water and ethanol extract [46].

Several studies reported that isolation of A. atroviolaceum leaves using different methods resulted in several essential oils such as dimethyl trisulfide, ethyl linolenate, phytol [73], norbornene, 3,4-dimethylthiophene, isocitronellene, methyl 1-propenyl disul- 
fide, dimethyl trisulfide furan, trans-2-(2-pentenyl)-furan, limonene, diallyl disulfide, 1,3-dithiane, 1,2-dithiolane, methyl (methylthio)methyl disulfide, 4,6-dimethyl-[1,2,3]trithiane, 5,9-undecadien-2-one, 6,10-dimethyl-(Z), 1,1'-thiobis-3-(methylthio)-propane, 4(2,6,6-trimethyl-1-cyclohexen-1-yl)-3-buten-2-one, 5-methyl-2-phenyl-2-hexenal, 2-methyl3-oxo-cis-cyclohexanebutanal, 1,2,4-cyclopentanetrione, 3-(2-pentenyl)-, di-2-propenyl tetrasulfide, formic acid, 1,2-dithiolane,1.1-dioxide, tetradecanoic acid, 1-(2-ethyl-[1,3]dithian-2yl)-3-methyl-butan-1-ol and 6,10,14-trimethylpentadecan-2-one [74] (Figure 9).<smiles>CSSSC</smiles>

159<smiles>C1=CC2CCC1C2</smiles>

162<smiles>CCCCC/C=C\C/C=C\CCCCCCC(=O)OCC</smiles>

160<smiles>CC(=CCO)CCCC(C)CCCC(C)CCCC(C)C</smiles>

161<smiles>Cc1cscc1C</smiles>

163<smiles>C=CCCC(C)C=C(C)C</smiles>

164<smiles>C=C(C)C1CC=C(C)CC1</smiles>

168<smiles>CSCSSC</smiles>

172<smiles>C/C=C/SSC</smiles>

165<smiles>CSSSc1ccco1</smiles>

166<smiles>C1CSCSC1</smiles>

170<smiles>CC/C=C/Cc1ccco1</smiles>

167<smiles>C1CSSC1</smiles>

171<smiles>CSCCCSCCCSC</smiles>

175<smiles>CC1C(=O)CCCC1CCCC=O</smiles>

178<smiles>O=CO</smiles>

181<smiles>CCC1(C(O)CC(C)C)SCCCS1</smiles>

184<smiles>C=CCSSCC=C</smiles>

169<smiles>CC1CC(C)SSS1</smiles>

173<smiles>CC(=O)/C=C/C1C(C)CCCC1(C)C</smiles>

176<smiles>CC/C=C/CC1C(=O)CC(=O)C1=O</smiles>

179<smiles>O=S1(=O)CCCS1</smiles>

182<smiles>CC(=O)CCCC(C)CCCC(C)CCCC(C)C</smiles>

185

Figure 9. Compounds obtained from A. atroviolaceum leaf extract using different isolation methods. (159) dimethyl trisulfide; (160) ethyl linolenate; (161) phytol [73]; (162) norbornene; (163) 3,4-dimethylthiophene; (164) isocitronellene; (165) methyl 1-propenyl disulfide; (166) dimethyl trisulfide furan; (167) trans-2-(2-pentenyl)-furan; (168) limonene; (169) diallyl disulfide; (170) 1,3-dithiane; (171) 1,2-dithiolane; (172) methyl (methylthio)methyl disulfide; (173) 4,6-dimethyl-[1-3]-trithiane; 
(174) 5,9-undecadien-2-one, 6,10-dimethyl-(Z); (175) 1,1'-thiobis-3-(methylthio)-propane; (176) 4-(2,6,6-trimethyl-1cyclohexen-1-yl)-3-buten-2-one; (177) 5-methyl-2-phenyl-2-hexenal; (178) 2-methyl-3-oxo-cis-cyclohexanebutanal; (179) 1,2,4cyclopentanetrione,3-(2-pentenyl)-; (180) di-2-propenyl tetrasulfide; (181) formic acid; (182) 1,2-dithiolane,1.1-dioxide; (183) tetradecanoic acid; (184) 1-(2-ethyl-[1,3]dithian-2-yl)-3-methyl-butan-1-ol; (185) 6,10,14-trimethylpentadecan-2-one [74].

\section{Allium Species Leave Bioactivity and Test Methods}

\subsection{Antimicrobial}

One of the activities found in several species Allium is as an antimicrobial. This activity serves as a source of antibiotics against microorganisms such as pathogens and microorganisms that can cause defects in food [75]. Amabye et al. reported that the antimicrobial activity of the ethanol extract of $A$. cepa leaves can inhibit the pathogen Streptococcus pneumoniae [40]. S. pneumoniae is a pathogen that has an important role in causing invasive diseases such as pneumonia, septicemia, meningitis and some types of eye infections [76-78]. An antimicrobial activity assay was carried out using the agar well diffusion with sterile dimethyl sulfoxide (DMSO) as a negative control and gentamicin as a positive control to determine the sensitivity of each bacterial species to be tested. The study showed that there was antimicrobial activity in the ethanol extract of $A$. cepa leaves, which managed to inhibit $S$. pneumoniae with an inhibition zone between 11.87-19.23 mm at $20 \mathrm{mg} / \mathrm{mL}$ and the minimum inhibitory concentrations (MIC) value at $10 \mathrm{mg} / \mathrm{mL}$.

In other studies also using the agar cup method, A. cepa leaf extract showed good antimicrobial activity in inhibiting the growth of bacteria and fungi such as Aspergillus sp., Botrytis sp. and Penicillium sp., each with an inhibition zone of 817 sq.mm, 817 sq.mm and 377 sq.mm, respectively [79]. Antimicrobial activity was also found in other Allium species such as A. ursinum [69], A. sativum to Listeria monocytogenes [78,79] and A. atroviolaceum [46]. Krivokapic et al. reported that antimicrobial activity was also present in A. ursinum leave. The test was carried out by the microdilution plate method to determine the MIC and minimum microbial concentration (MMC) value. The result indicated that the leaf extract had antimicrobial activity inhibiting the growth of 20 bacteria and fungi [10]. Other studies also state that $A$. ursinum leaf extracts contain organosulfur compounds such as propylene sulfide, $(E)$ methyl-2-propenyl disulfide and $(Z)$ methyl-2-propenyl disulfide and several other compounds that have antimicrobial activity [72].

\subsubsection{Antibacterial}

Research conducted by Solomon et al. reported the presence of antibacterial activity in A. cepa leaves with different types of extracts, namely ethanol extract, hot extract and cold extract. The three extracts were compared to see the difference in their compound content and the efficiency of their antibacterial activity. The hot extract contains more flavonoids and saponins than the other two extracts. Hot extract also showed the best antibacterial activity among ethanol extract and cold extract in inhibiting the growth of Escherichia coli, Streptococcus and Stephylus [80].

\subsubsection{Antifungal}

Parvu et al. reported that the ethanol extract of $A$. ursinum leaves has antifungal activity. This study uses the agar dilution assay by determining the MIC value. Although the content of allicin compounds in the leaves is not as much as in the flowers, the antifungal activity in the ethanol extract of $A$. ursinum leaves is able to fight several types of fungi with the MIC value of $120 \mu \mathrm{L} / \mathrm{mL}$ (A. niger), $80 \mu \mathrm{L} / \mathrm{mL}$ (B. cinerea), $100 \mu \mathrm{L} / \mathrm{mL}$ (B. paeoniae), $160 \mu \mathrm{L} / \mathrm{mL}$ (F. oxysporum f. sp. tulipae), $120 \mu \mathrm{L} / \mathrm{mL}$ (P. gladioli) and $80 \mu \mathrm{L} / \mathrm{mL}$ (S. sclerotiorum) [21].

\subsection{Antioxidant}

Research on antioxidant activity in Allium species has been widely reported. Antioxidant activity is found in many Allium species with different test methods. Dominguez et al. reported the antioxidant activity of $A$. schoenoprasum based on the total iron reduction's 
potential technique [62]. In several studies, the antioxidant activity test of $A$. schoenoprasum and $A$. ursinum used different methods such as DPPH radical-scavenging ability, ferric reducing antioxidant power (FRAP) assay and ABTS radical scavenging assays $[17,52,54,55]$. The use of some of these methods is intended to compare the results of activities between one method and another and to determine which method is more appropriate to be used in certain species. Parvu et al. did the same, which uses two methods, namely DPPH bleaching method and the trolox equivalent antioxidant capacity (TEAC) assay, where the antioxidant activity of the leaf extract was shown to be higher by the TEAC method than DPPH bleaching method [64].

\subsection{Anti-Inflammatory}

Inflammation is a condition in which catabolism is more dominant or faster than anabolism [81]. Inflammation can also be defined as a reaction to defend the body in eliminating factors that can cause damage and the formation of homeostasis in the body. This causes increased blood flow due to the increased permeability of capillaries and white blood cells to the site of inflammation, resulting in inflammatory symptoms such as redness, swelling and pain [82]. Several previous studies reported that the Allium species has several bioactivities, one of which is anti-inflammatory [83-87]. Parvu et al. reported that $A$. schoenoprasum leaf extract with three different concentrations (25, 50 and $100 \%)$ had anti-inflammatory activity. The research was conducted by the method of testing in vivo using a turpentine oil-induced inflammation model, while in terms of in vitro, the three extracts were able to inhibit phagocytosis by reducing nitro-oxidative stress [64].

Pan et al. reported that anti-inflammatory activity was also present in A. sativum aqueous leaf extract. The extract was previously screened for phytochemicals. The results showed that the extract contained carbohydrates, reducing sugars, lipids, flavonoids, ketones, alkaloids, steroids and triterpenes. The study used two different anti-inflammatory activity testing methods, namely carrageenan-induced paw edema and histamine-induced paw edema. Both methods showed that $A$. sativum aqueous leaf extract was able to lower the paw edema significantly [88]. The same activity is also found in A. fistulosum aqueous leaf extract or welsh onions. However, this study only used a carrageenan-induced paw edema method. The results showed that the aqueous extract was able to inhibit the development of paw edema by reducing the activity of the catalase (CAT), superoxide dismutase (SOD) and glutathione peroxidase (GPx) enzymes found in paw edema mice by 43,74 and $50 \%$, respectively [87].

\subsection{Antitumor}

Tumors are pathological cells that can interfere with cell growth to be abnormal. Tumors, often called neoplasms, are divided into benign tumors and malignant tumors. Malignant tumors are often referred to as cancer [89]. The prevention and cure of tumors can be obtained from natural ingredients that contain compounds that have antitumor activity. A number of Allium species are known to have antitumor activity, such as $A$. cepa, A. sativum, A. fistulosum and A. schoenoprasum [90]. Shirshova et al. reported that the aqueous and $\mathrm{EtOH}-\mathrm{H}_{2} \mathrm{O}$ extract of $A$. schoenoprasum leaves have antitumor activity. Several compounds such as sitosterol, stigmasterol, campesterol, cholesterol, deltonin, saponin $\mathrm{A}$ and mono-, di- and triacylglycerin were isolated and tested for antitumor activity in 40 male BDF mice. EtOH- $\mathrm{H}_{2} \mathrm{O}$ extract of $A$. schoenoprasum leaves was given to mice that have been divided into four groups and given previous treatment and injected with tumor strains Ehrlich carcinoma (EC). The results showed that the extract of $A$. schoenoprasum leaves can inhibit tumor growth. The results can be seen by comparing tumor volume and mass between the experimental group and the control group [67].

\subsection{Antiplatelet}

Platelets are small cell fragments that clump in the area of the injured blood vessel [91]. Platelets have an important role in hemostasis, which functions in stopping bleeding [92]. 
Dysfunctional or abnormal platelets can cause cardiovascular damage, such as myocardial infarctions and strokes. Several studies have developed antiplatelet drugs such as aspirin to overcome the problem of abnormal platelets [93]. Several studies have reported that some Allium species have antiplatelet activity. Saplonţai-Pop et al. reported that $A$. cepa bulbs have antiplatelet activity. The activity test used platelet-rich plasma (PRP), which is based on the kinetic curve of decreasing plasma OD [94], while the research conducted by Ko et al. used the platelet aggregation turbidometric assay [95]. Hiyasat et al. reported that A. ursinum leaf extract has antiplatelet activity. Testing of antiplatelet activity in vitro was conducted using light transmission aggregometry which has been induced with adenosine diphosphate (ADP), collagen, A23187, epinephrine and arachidonic acid (ARA) [17]. In other species such as A. fistulosum and A. schoenoprasum was also found the presence of antiplatelet activity using the electrical impedance aggregator method. Although the activities possessed by these two species are not as good as in other species, such as $A$. sativum and A. ascalonicum [65]. While A. atroviolaceum extract has excellent antiplatelet activity and is able to inhibit platelet aggregation in vitro induced by ARA and ADP with each $\mathrm{IC}_{50}$ value of $0.4881(0.4826-0.4937)$ and $0.4945(0.4137-0.5911) \mathrm{mg} / \mathrm{mL}$ [74].

\subsection{Pancreatic $\alpha$-Amylase and Glucoamylase Enzyme Inhibitor}

The reduction of carbohydrate digestion can be carried out by controlling the activity of hydrolysis enzymes, $\alpha$-amylase and glucoamylase. Controlling this activity can affect postprandial hyperglycemia, which is considered to have a prophylactic healing effect in patients with type 2 diabetes mellitus [96]. The inhibition of hydrolytic enzyme activity is one of the right efforts to suppress carbohydrate digestion and monosaccharide absorption [97]. In human physiology, pancreatic $\alpha$-amylase is a type of $\alpha$-amylase which is found in plants, fungi and bacteria [98]. The amount of pancreatic $\alpha$-amylase synthesized in the rough endoplasmic reticulum is regulated by the amount of food substrates [99], whereas glucoamylase is an enzyme that can be produced from a number of organisms such as Aspergillus niger and Aspergillus awamori. This enzyme plays a role in producing a certain amount of glucose [100] (Table 1).

Meshram and Khamkar succeeded in isolating oleanolic acid compounds from the chloroform fraction of A. sativum leaves using an enzyme activity inhibition test of pancreatic $\alpha$-amylase and glucoamylase carried out by the Miller method [101], which was modified. The study reported that oleanolic acid showed excellent inhibition of both enzymes. The highest inhibition value occurred at a concentration of $100 \mu \mathrm{g} / \mathrm{mL}$ was $57.50 \%$ with $\mathrm{IC}_{50} 83.56 \mu \mathrm{g} / \mathrm{mL}$ for the glucoamylase enzyme, while it was $62.43 \%$ for pancreatic $\alpha$-amylase with $\mathrm{IC}_{50} 55.51 \mu \mathrm{g} / \mathrm{mL}$ [53].

Table 1. Test Methods for Antioxidant Activity and Other Bioactivities of Allium Species Leaves.

\begin{tabular}{|c|c|c|}
\hline Species & Antioxidant Test Methods & Other Bioactivities \\
\hline A. sativum & The phosphomolybdenum reduction assay [102] & $\begin{array}{l}\text { Antimicrobial [103,104]; Anti-inflammatory [88]; } \\
\text { Inhibitor pancreatic } \alpha \text {-amylase and glucoamylase [53] }\end{array}$ \\
\hline A. ursinum & $\begin{array}{c}\text { DPPH radical-scavenging ability [70,71,105]; ferric reducing } \\
\text { antioxidant power (FRAP) assay [68]; ABTS radical scavenging } \\
\text { assays [23] }\end{array}$ & Antimicrobial [72,105]; Antifungal [21]; Antiplatelet [17] \\
\hline A. schoenoprasum & $\begin{array}{l}\text { DPPH radical-scavenging ability; ferric reducing antioxidant } \\
\text { power (FRAP) assay [68]; DPPH bleaching method; the Trolox } \\
\text { equivalent antioxidant capacity (TEAC) assay [64]; the total iron } \\
\text { reduction's potential technique [62]; ORAC (oxygen radical } \\
\text { absorbance capacity) [65] }\end{array}$ & Anti-inflammatory [73]; Antitumor [67]; Antiplatelet [65] \\
\hline A. fistulosum & $\begin{array}{l}\text { DPPH free radical scavenging assay [61]; ORAC (oxygen radical } \\
\text { absorbance capacity) [65] }\end{array}$ & Anti-inflammatory [87]; Antiplatelet [65] \\
\hline A. scorodoprasum & $\begin{array}{l}\text { Ferric reducing/antioxidant power (FRAP); DPPH radical } \\
\text { scavenging activity assay [12] }\end{array}$ & - \\
\hline A. vineale & $\begin{array}{l}\text { Ferric thiocyanate method; ferric ions }\left(\mathrm{Fe}^{3+}\right) \text { reducing antioxidant } \\
\text { power assay (FRAP); DPPH free radical-scavenging activity [16] }\end{array}$ & - \\
\hline
\end{tabular}


Table 1. Cont.

\begin{tabular}{ccc}
\hline Species & Antioxidant Test Methods & Other Bioactivities \\
\hline A. cepa & Antioxidant enzyme method [27] & $\begin{array}{c}\text { Antimicrobial [40,79]; Antibacterial [80]; } \\
\text { Anticardioprotective [49] }\end{array}$ \\
\hline A. flavum & - & Anticancer [11] \\
\hline A. atroviolaceum & - & Antimicrobial [46]; Antiplatelet [74] \\
\hline
\end{tabular}

\section{Antioxidant Properties}

Antioxidants are a system to protect our bodies from osulfide, allyl methyl tetrasulfide, allyl (methylthio)methyl trisulfide, 4-mexidative stress caused by free radical and reactive oxygen species (ROS) [48]. Oxidative stress can occur due to the formation of ROS and the detoxification of increased levels of ROS in balance, causing impaired cellular function [106]. Oxidative stress due to ROS can cause several chronic diseases such as cancer, coronary heart disease and osteoporosis. Free radical reactions can attack biomolecules, especially the polyunsaturated fatty acids of cell membranes. ROS which are included as free radicals include superoxide anion $\left(\mathrm{O}_{2}{ }^{\bullet-}\right)$, perhydroxyl radicals $\left(\mathrm{HO}_{2}{ }^{\bullet}\right)$, hydroxyl radicals $\left({ }^{\bullet} \mathrm{OH}\right)$ and nitric oxide and other species such as hydrogen peroxide $\left(\mathrm{H}_{2} \mathrm{O}_{2}\right)$, singlet oxygen $\left({ }^{1} \mathrm{O}_{2}\right)$, hypochloric acid $(\mathrm{HOCl})$ and peroxynitrite $\left(\mathrm{ONOO}^{-}\right)[107,108]$. The formation of ROS starts from the uptake of $\mathrm{O}_{2}$, then activates NADPH oxidase and produces superoxide anion radicals and continues with the conversion of $\mathrm{O}_{2}$ that becomes $\mathrm{H}_{2} \mathrm{O}_{2}$ by SOD [109]. Antioxidants break the chain of free radical reactions by donating their own electrons to free radicals without becoming free radicals [106,110].

Based on their activity, antioxidants are classified into two types, which are enzymatic and non-enzymatic. Enzymatic antioxidants are antioxidants that involve several enzymes such as GPx, CAT and SOD in catalyzing free radical and ROS neutralization reactions, while non-enzymatic antioxidants can come from natural materials such as fruits, onions and others. These natural materials contain several compounds that have antioxidant activity such as flavonoids, alkaloids, carotenoids and phenolic groups [111]. Testing of antioxidant activity can be carried out by some test methods such as DPPH free radical scavenging assay, oxygen radical absorbance capacity (ORAC) assay, trolox equivalent antioxidant capacity (TEAC) assay, ferric reducing antioxidant power (FRAP) assay, cupric reducing antioxidant capacity (CUPRAC) assay, reducing power assay and other methods [112-114].

Antioxidant compounds can also be obtained from some Allium species such as $A$. fistulosum, A. ursinum, A. schoenoprasum, A. flavum, A. cepa, A. scorodoprasum, A. sativum, A. cepa and $A$. vineale $[69,70,102]$. These compounds can be isolated from all parts of the plant such as bulbs, leaves, roots, flowers and bark [109]. This study will discuss the antioxidant activity of the compounds contained in Allium species leaves.

Testing of antioxidant activity in the species $A$. sativum was carried out using the DPPH and FRAP assay. Some studies reported that the antioxidant activity of the A. sativum leaves is very high, with $\mathrm{IC}_{50} 7.21 \pm 0.39 \mathrm{mg} / \mathrm{mL}$ in the DPPH assay and $7.99 \mathrm{~mol} / \mathrm{g}$ in the FRAP assay [114]. In 2005, Kim et al. succeeded in isolating four flavonol compounds from $A$. sativum leaves. These compounds are quercetin 3-O- $\beta$-D-glucopyranoside (isoquercitrin), quercetin 3-O- $\beta$-D-xylopyranoside (reynoutrin), kaempferol 3-O- $\beta$-D-glucopyranoside (astragalin) and isorhamnetin 3-O- $\beta$-D-glucopyranoside. The four compounds were tested for their antioxidant activity using the DPPH method, hydroxyl radical-scavenging activity and the ferric thiocyanate method [57]. Singh and Kumar also reported the presence of antioxidant activity in A. sativum leaves using the phosphomolybdenum reduction assay. The method is based on the reduction of Mo (IV) to Mo (V) in the methanol extract by formatting a green phosphate complex subsequence or Mo (V) [102].

El Hadidy et al. reported that there were three major compounds isolated from $A$. fistulosum leaf extract. They are myricetin, quercetin and rutin. From the three compounds, myricetin is the most abundant compound in the Giza 6 and photon varieties, among 
other compounds, which is $38.75 \%$. The antioxidant activity test using the DPPH method showed that the activity decreased after three months of storage based on the percentage of antioxidants [61]. The ethanol extract of $A$. ursinum leaves, which also uses the DPPH radical scavenging assay, showed antioxidant activity of $77 \%$ with an $\mathrm{EC}_{50}$ value $322 \mathrm{~g} / \mathrm{mL}$. The activity was influenced by the presence of phenolic compounds in the extract [69]. Research on antioxidant activity was also carried out on A. schoenoprasum leaves which used two methods, DPPH bleaching assay and TEAC. The results using DPPH showed weak antioxidant activity with an $\mathrm{EC}_{50}$ value $(6.72 \pm 0.44 \mathrm{~g} / \mathrm{mg})$, whereas the TEAC method used to determine the total oxidant scavenging activity showed a value of $132.8 \pm 23 \mathrm{~g}$ Trolox eq./g [64].

\section{Structure-Antioxidant Activity Relationship Compounds in Allium}

The structure-activity relationship (SAR) is an approach used to determine the relationship between the structure of a compound and its bioactivity [115]. The presence of certain substituents can affect the strength of compound activity; for example, the different number and position of a hydroxyl group will provide different antioxidant activities [116]. The following are some of the compound structures that have been isolated from Allium leaf extract: (Figure 10).<smiles>O=c1cc(-c2ccc(O)cc2)oc2cc(O)cc(O)c12</smiles>

186<smiles>CC(=O)c1c(O)cc(O)cc1OC1CC(=O)c2cc(O)ccc2O1</smiles>

189<smiles>Oc1cc(O)c2c(c1)OC(c1ccc(O)c(O)c1)C(O)C2</smiles>

190<smiles>O=c1c(O)c(-c2cc(O)c(O)c(O)c2)oc2cc(O)cc(O)c12</smiles>

187<smiles>O=c1c(O)c(-c2ccc(O)cc2)oc2cc(O)cc(O)c12</smiles>

188<smiles>O=c1c(O)c(-c2ccc(O)c(O)c2)oc2cc(O)cc(O)c12</smiles>

191

Figure 10. Compound structures are successfully isolated from Allium leaf extracts. (186) apigenin [35]; (187) myricetin [117]; (188) naringenin [118]; (189) kaempferol [119]; (190) catechin [120]; (191) quercetin [121].

\subsection{Apigenin}

Apigenin ( $4^{\prime}, 5,7$-trihydroxy-flavone) is a compound that has been isolated from the A. fistulosum leaves, such as in a study conducted by Immaculate $\mathrm{V}$. et al. This compound shows a bright orange color when observed under UV light with an Rf value (0.83). Based on HPLC analysis data, this compound showed one major peak at $2.629 \mathrm{~min}$ and nine minor peaks $(10.700 ; 13.604 ; 15.744 ; 17.324 ; 18.579 ; 19.525 ; 19.683 ; 21.360 ; 25.383)$, in minutes [34]. Li et al. reported that apigenin has low antioxidant activity, which is due to the absence of a single hydroxyl group in ring $\mathrm{A}$ and a single hydroxyl group in ring $\mathrm{B}$ with an activity value $(1.5 \mathrm{mM})[122]$. 


\subsection{Myricetin}

Myricetin ( $3^{\prime}, 4^{\prime}, 5^{\prime}, 3,5,7$-hexahydroxyflavone) was also isolated from A. fistulosum. This compound is classified into the flavonoid group, which has six hydroxyl groups at positions $3,5,7,3^{\prime}, 4^{\prime}$ and $5^{\prime}$ [117]. The presence of a hydroxyl group at position $5^{\prime}$ in ring $B$ greatly affects its antioxidant activity so that it becomes stronger with the $\mathrm{IC}_{50}(4 \mu \mathrm{M})$ and $463.40 \pm 22.28 \mu \mathrm{M}$ in testing using DPPH radical scavenging activity $[118,120,123]$.

\subsection{Naringenin}

Naringenin 4',5,7-trihydroxyflavanon is a flavanone compound of the flavonoid group with a molecular weight of $272.26\left(\mathrm{C}_{15} \mathrm{H}_{12} \mathrm{O}_{5}\right)$ [124-127]. This compound had been isolated from $A$. fistulosum [61]. It has a saturated heterocyclic ring $C$ with hydroxyl substituent at positions $4^{\prime}, 5,7$. The presence of a hydroxyl group in ring A and a single hydroxyl group in ring $B$ affect the naringenin value in the TEAC test $(1.5 \pm 0.05 \mathrm{mM})$, so that its antioxidant activity is lower than that of quercetin which has two hydroxyl substituents in ring B $[122,124]$.

\subsection{Kaempferol}

Kaempferol can be found in fruits and vegetables [102,115]. This compound is also easily found in some Allium species [119]. In recent years, several studies had reported the presence of kaempferol in A. fistulosum, A. ursinum, A. schoenoprasum, A. sativum and other species [40,103]. Kaempferol (3,4',5,7-tetrahydroxyflavone) is a yellow tetrahydroxyflavone compound that belongs to the flavonoid group with hydroxyl groups at positions 3, 4', 5 , and $7[115,122,127]$. Kaempferol has a wavelength band $(367 \mathrm{~nm})$ which is longer than compounds that only have three hydroxyl groups such as apigenin $(337 \mathrm{~nm})$. The presence of a reduction of the 2,3-unsaturated bond in ring $C$ did not affect its antioxidant activity, whereas the presence of a single hydroxyl group in ring $B$, which is conjugated with a conjugated double bond, has little effect on increasing antioxidant activity [124]. Farkas et al. reported that kaempferol has antioxidant activity in inhibiting heat-induced oxidation in a $\beta$-carotene-linoleic acid-model-system (65.3\%) [128]. In testing using the DPPH radical scavenging activity method, kaempferol has an $\mathrm{IC}_{50}$ value $28.05 \pm 0.28 \mu \mathrm{M}$ and $1.3 \pm 0.08 \mathrm{mM}$ in tests using the TEAC (Trolox equivalent antioxidant activity) $[129,130]$.

\subsection{Catechin}

Catechin $\left(3,3^{\prime}, 4^{\prime}, 5,7-\right.$ pentahydroxyflavan) is a compound commonly found in several types of green tea, cocoa, red grapes and onions [49,120,131-133]. It also can be found and isolated from A. schoenoprasum [62]. This compound belongs to flavanol compound groups which have five hydroxyl substituents at positions $3,3^{\prime}, 4^{\prime}, 5$ and 7 [133]. In recent years, this compound had been reported to have antioxidant activity $[125,133]$. Silva et al. reported that catechin had antioxidant activity of $1.9 \pm 0.1 \mu \mathrm{mol}$ in the DPPH radical scavenging assay and $1.4 \pm 0.3 \mu \mathrm{M}$ trolox equivalents $/ \mu \mathrm{M}$ flavonoids in the ORAC $\mathrm{ROO}$ assay. $o$-catechol group in ring B showed a good effect on antioxidant activity [134]. In addition, the high planarity due to the intramolecular hydrogen bonding between the $3-\mathrm{OH}$ and $6^{\prime}-\mathrm{H}$ substituents in flavanol compounds such as catechin can also provide a good antioxidant activity [135,136].

\subsection{Quercetin}

Quercetin (3,5,7,3', $4^{\prime}$-pentahydroxyflavon) is one of the flavonoid compounds found in plants such as onions, apples, berries and others. Its presence can be easily found in several Allium species such as A. cepa, A. sativum, A. ursinum and A. fistulosum $[4,56]$. This flavonol compound consists of three rings and five hydroxyl groups $[123,137,138]$. Several studies reported that quercetin has the ability as an antioxidant in reducing the formation of ROS [139-145]. The strength of antioxidant activity depends on the number of hydroxyl groups possessed, such as quercetin, which will provide stronger activity than naringenin and apigenin with three hydroxyl groups $[116,117,121]$. This is indicated by the value of 
$\mathrm{IC}_{50}$ that is smaller and TEAC values that are larger compared to the two compounds with each IC $50(10.89 \pm 0.03 ;>1000 ; 463.40 \pm 22.28 \mu \mathrm{M})$ and TEAC $(4.7,1.53,1.45 \mathrm{mM})$ [118-142]. At the same time, the formation of a resonance-stabilized quinone structure due to the hydroxyl group adjacent to the ring C [125]. Antioxidant activity will decrease when there is glycolation of the hydroxyl group at position 3 on ring C [121].

\section{Conclusions}

Allium species such as A. cepa, A. sativum, A. fistulosum, A. schoenoprasum, A. ursinum, A. flavum, A. scorodoprasum, $A$. vineale and $A$. atroviolaceum have a great role in the health field. Those contain secondary metabolites that have several bioactivities such as antioxidant, antimicrobial, antibacterial, antifungal, anti-inflammatory and others. Their bioactivities are influenced by certain structure and functional groups.

Author Contributions: Conceptualization, D.K. and D.S.; methodology, D.A. and L.H.; validation, D.K. and D.S.; formal analysis, D.A.; resources, D.A., D.K. and L.H.; data curation, D.A.; writingoriginal draft preparation, D.A.; writing-review and editing, D.A. and D.K.; visualization, D.A.; supervision, D.K.; project administration, D.K.; funding acquisition, D.K. and L.H. All authors have read and agreed to the published version of the manuscript.

Funding: This research was funded by the Education Fund Management Institution or Lembaga Pengelola Dana Pendidikan (LPDP), Indonesia (20200811303200).

Institutional Review Board Statement: Not applicable.

Informed Consent Statement: Not applicable.

Data Availability Statement: The study did not report any data.

Acknowledgments: The authors are grateful to the Central Library of Universitas Padjadjaran for the deposit of supplementary material, the Education Fund Management Institution or Lembaga Pengelola Dana Pendidikan (LPDP), Indonesia, and also grateful to Universitas Padjadjaran for supporting all research facilities.

Conflicts of Interest: The authors declare no conflict of interest.

\section{References}

1. Shahidi, F.; Zhong, Y. Measurement of antioxidant activity. J. Funct. Foods 2015, 18, 757-781. [CrossRef]

2. Brainina, K.; Stozhko, N.; Vidrevich, M. Antioxidants: Terminology, Methods, and Future Considerations. Antioxidants 2019, 8 , 297. [CrossRef] [PubMed]

3. White, P.; Oliveira, R.; Oliveira, A.; Serafini, M.; Araújo, A.; Gelain, D.; Moreira, J.; Almeida, J.; Quintans, J.; Quintans-Junior, L.; et al. Antioxidant Activity and Mechanisms of Action of Natural Compounds Isolated from Lichens: A Systematic Review. Molecules 2014, 19, 14496-14527. [CrossRef] [PubMed]

4. Cheng, H.; Huang, G.; Huang, H. The antioxidant activities of garlic polysaccharide and its derivatives. Int. J. Biol. Macromol. 2020, 145, 819-826. [CrossRef]

5. Stanisavljević, N.; Soković Bajić, S.; Jovanović, Ž.; Matić, I.; Tolinački, M.; Popović, D.; Popović, N.; Terzić-Vidojević, A.; Golić, N.; Beškoski, V.; et al. Antioxidant and Antiproliferative Activity of Allium ursinum and Their Associated Microbiota During Simulated in vitro Digestion in the Presence of Food Matrix. Front. Microbiol. 2020, 11, 601616. [CrossRef]

6. González-de-Peredo, A.V.; Vázquez-Espinosa, M.; Espada-Bellido, E.; Carrera, C.; Ferreiro-González, M.; Barbero, G.F.; Palma, M. Flavonol Composition and Antioxidant Activity of Onions (Allium cepa L.) Based on the Development of New Analytical Ultrasound-Assisted Extraction Methods. Antioxidants 2021, 10, 273. [CrossRef]

7. Gitin, L.; Dinica, R.; Parnavel, R. The Influence of Extraction Method on the Apparent Content of Bioactive Compounds in Romanian Allium spp. Leaves. Not. Bot. Horti Agrobot. 2012, 40, 93. [CrossRef]

8. Verma, V.; Pradheep, K.; Khar, A.; Negi, K.; Rana, J. Collection and Characterization of Allium Species from Himachal Pradesh. Indian J. Plant Genet. Resour. 2008, 21, 225-228.

9. Verma, S.; Kaur, S.; Singh, J.; Garg, A. Anti-bacterial Effect of Garlic (Allium sativum L.) Extract on Different Pathogenic and Non-pathogenic Bacteria. RJPBCS 2015, 6, 1103.

10. Krivokapic, M.Z.; Tomovic, M.T.; Jakovljevic, V.L.; Sovrlic, M.M.; Bradic, J.V.; Petkovic, A.M.; Radojevic, I.D.; Brankovic, S.R.; Comic, L.R.; Andjic, M.M.; et al. Biological activities of different extracts from Allium ursinum leaves. Acta Pol. Pharm. Drug Res. 2020, 77, 121-129. [CrossRef]

11. Rezgui, A.; Mitaine-Offer, A.-C.; Paululat, T.; Delemasure, S.; Dutartre, P.; Lacaille-Dubois, M.-A. Cytotoxic Steroidal Glycosides from Allium flavum. Fitoterapia 2014, 93, 121-125. [CrossRef] 
12. Taşc1, B.; Kütük, H.; Koca, İ. Antioxidant Activity of Allium scorodoprasum L. subsp. rotundum (L.) Stearn Plant Grown in Turkey. Turk. J. Agric. Food Sci. Technol. 2019, 7, 1561. [CrossRef]

13. Kothari, D.; Lee, W.-D.; Kim, S.-K. Allium Flavonols: Health Benefits, Molecular Targets, and Bioavailability. Antioxidants 2020, 9 , 888. [CrossRef]

14. Aydin, Ç.; Mammadov, R. Phytochemical analysis, phenolic content, antioxidant, antibacterial, insecticidal and cytotoxic activites of Allium reuterianum Boiss. extracts. Indian J. Tradit. Knowl. 2019, 9, 290-298. Available online: http://nopr.niscair.res.in/ handle/123456789/47083 (accessed on 15 November 2021).

15. Chehregani, A.; Azimishad, F.; Alizade, H.H. Study on Antibacterial Effect of Some Allium Species from Hamedan-Iran. Int. J. Agri. Biol. 2007, 9, 6.

16. Demirtas, I.; Erenler, R.; Elmastas, M.; Goktasoglu, A. Studies on the antioxidant potential of flavones of Allium vineale isolated from its water-soluble fraction. Food Chem. 2013, 136, 34-40. [CrossRef]

17. Hiyasat, B.; Sabha, D.; Grötzinger, K.; Kempfert, J.; Rauwald, J.-W.; Mohr, F.-W.; Dhein, S. Antiplatelet Activity of Allium ursinum and Allium sativum. Pharmacology 2009, 83, 197-204. [CrossRef]

18. Durmaz, H.; Sagun, E.; Tarakci, Z.; Ozgokce, F. Antibacterial activities of Allium vineale, Chaerophyllum macropodum and Prangos ferulacea. Afr. J. Biotechnol. 2006, 5, 1795-1798.

19. Fredotović, Ž.; Šprung, M.; Soldo, B.; Ljubenkov, I.; Budić-Leto, I.; Bilušić, T.; Čikeš-Čulić, V.; Puizina, J. Chemical Composition and Biological Activity of Allium cepa L. and Allium $\times$ cornutum (Clementi ex Visiani 1842) Methanolic Extracts. Molecules 2017, 22, 448. [CrossRef]

20. Kopeć, A.; Skoczylas, J.; Jędrszczyk, E.; Francik, R.; Bystrowska, B.; Zawistowski, J. Chemical Composition and Concentration of Bioactive Compounds in Garlic Cultivated from Air Bulbils. Agriculture 2020, 10, 40. [CrossRef]

21. Pârvu, M.; Pârvu, A.E.; Vlase, L.; Rosca-Casian, O.; Pârvu, O. Antifungal Aroperties of allium ursinum L. Ethanol Extract. J. Med. Plants Res. 2011, 5, 2041-2046.

22. Pejatović, T.; Samardžić, D.; Krivokapić, S. Antioxidative properities of a traditional tincture and several leaf extracts of Allium ursinum L. (collected in Montenegro and Bosnia and Herzegovina). J. Mater. Environ. Sci. 2017, 8, 1929-1934.

23. Sapunjieva, T.; Alexieva, I.; Mihaylova, D.; Popova, A. Antimicrobial and antioxidant activity of extracts of Allium ursinum L. J. BioSci. Biotech. 2012, 3, 143-145.

24. Štajner, D.; Čanadanović-Brunet, J.; Pavlović, A. Allium schoenoprasum L., as a natural antioxidant. Phytother. Res. 2004, 18, 522-524. [CrossRef] [PubMed]

25. Tóth, T.; Kovarovič, J.; Bystrická, J.; Vollmannová, A.; Musilová, J.; Lenková, M. The content of polyphenols and antioxidant activity in leaves and flowers of wild garlic (Allium ursinum L.). Acta Aliment. 2018, 47, 252-258. [CrossRef]

26. Upadhyay, R. Nutritional and Therapeutic Potential of Allium Vegetables. J. Nutr. Ther. 2017, 6, 18-37. [CrossRef]

27. Stajner, D.; Varga, I.S. An evaluation of the antioxidant abilities of Allium species. Acta Biol. Szeged. 2003, 47, 103-106.

28. Upadhyay, R.K. Nutraceutical, pharmaceutical and therapeutic uses of Allium cepa: A review. Int. J. Green Pharm. 2016, 10, 19.

29. Lim, T.K. Edible Medicinal and Non-Medicinal Plants; Springer: Dordrecht, The Netherlands, 2012; ISBN 978-90-481-8660-0.

30. Koske, T. Allium Crops Onions Shallots and Garlic. LSU AgCenter Reserch \& Ext. 1914. Available online: https:// www.lsuagcenter.com/NR/rdonlyres/9E30F191-2704-4BB9-A051-7A3FF7D9715E/44481/pub2318AlliumCropsLOWRES.pdf (accessed on 15 November 2021).

31. Peterson, J. The Allium Species (Onions, Garlic, Leeks, Chives, and Shallots). Camb. World Hist. Food 2013, 249-271. [CrossRef]

32. Newenhouse, A. Growing Fresh Market Onions, Garlic, and Leeks; University of Wisconsin: Madison, WI, USA, $2011 ;$ pp. 1-39.

33. Sanjay, S.S.; Kn, D.; Db, R.; Kabbinavar, S.; Zaranappa, D. Phytochemicals and Potential Biological Activities of Allium sativum Linn. J. Pharmacogn. Phytochem. 2018, 7, 662-670.

34. Mikaili, P.; Maadirad, S.; Moloudizargari, M.; Aghajanshakeri, S. Therapeutic Uses and Pharmacological Properties of Garlic, Shallot, and Their Biologically Active Compounds. Iran. J. Basic Med. Sci. 2013, 16, 18.

35. Immaculate, V.T.M.; Shlini, P.; Mary Clare, H. Isolation and Purification of Apigenin From Allium fistulosum. Int. J. Curr. Pharm. Res. 2020, 12, 67-71. [CrossRef]

36. Bede, D.; Zaixiang, L. Dietary Polysaccharides from Allium Species: A Critical Review in Dietary Polysaccharides from Allium Species: Extraction, Characterization, Bioactivity, And Potential Utilization. Acta Sci. Agric. 2020, 4, 1-15. [CrossRef]

37. Egert, M.; Tevini, M. Influence of drought on some physiological parameters symptomatic for oxidative stress in leaves of chives (Allium schoenoprasum). Environ. Exp. Bot. 2002, 48, 43-49. [CrossRef]

38. Singh, V.; Chauhan, G.; Krishan, P.; Shri, R. Allium schoenoprasum L.: A review of phytochemistry, pharmacology and future directions. Nat. Prod. Res. 2018, 32, 2202-2216. [CrossRef]

39. Lachowicz, S.; Kolniak-Ostek, J.; Oszmiański, J.; Wiśniewski, R. Comparison of Phenolic Content and Antioxidant Capacity of Bear Garlic (Allium ursinum L.) in Different Maturity Stages: Phenolics and Antioxidants in Bear Garlic. J. Food Process. Preserv. 2017, 41, e12921. [CrossRef]

40. Gebregiorgis Amabye, T. In Vitro Antimicrobial Efficacy of Fractions from Onion (Allium cepa) Leaves Extract from Wukro, Ethiopia. Am. J. Life Sci. 2015, 3, 365. [CrossRef]

41. Curcic, M.G.; Stankovic, M.S.; Radojevic, I.D.; Stefanovic, O.D.; Comic, L.R.; Topuzovic, M.D.; Djacic, D.S.; Markovic, S.D. Biological Effects, Total Phenolic Content and Flavonoid Concentrations of Fragrant Yellow Onion (Allium flavum L.). Med. Chem. 2012, 8, 46-51. [CrossRef] 
42. Firat, M. The Ethnobotanical Usage of Some East Anatolian (Turkey) Allium L. Species. Manas J. Agric. Vet. Life Sci. 2015, 5, 80-86.

43. Tasci, B.; Koca, I. Use of Allium scorodoprasum L. subsp. rotundum as food. Acta Hortic. 2016, 153-158. [CrossRef]

44. Defelice, M.S. Wild Garlic, Allium vineale L.-Little to Crow About. Weed Technol. 2003, 17, 890-895. [CrossRef]

45. Satyal, P.; Craft, J.; Dosoky, N.; Setzer, W. The Chemical Compositions of the Volatile Oils of Garlic (Allium sativum) and Wild Garlic (Allium vineale). Foods 2017, 6, 63. [CrossRef]

46. Hafeznia, B.; Anvar, S.A.; Kakoolaki, S.; Choobkar, N. Antimicrobial efficiency of Allium atroviolaceum extract on Rainbow trout in different temperature and storage time. Iran. J. Aquat. Anim. Health 2018, 4, 86-94. [CrossRef]

47. Khazaei, S.; Abdul Hamid, R.; Ramachandran, V.; Mohd Esa, N.; Pandurangan, A.K.; Danazadeh, F.; Ismail, P. Cytotoxicity and Proapoptotic Effects of Allium atroviolaceum Flower Extract by Modulating Cell Cycle Arrest and Caspase-Dependent and $p 53$ -Independent Pathway in Breast Cancer Cell Lines. Evid.-Based Complement. Alternat. Med. 2017, 2017, 1-16. [CrossRef]

48. Schwinn, K.E.; Ngo, H.; Kenel, F.; Brummell, D.A.; Albert, N.W.; McCallum, J.A.; Pither-Joyce, M.; Crowhurst, R.N.; Eady, C.; Davies, K.M. The Onion (Allium cepa L.) R2R3-MYB Gene MYB1 Regulates Anthocyanin Biosynthesis. Front. Plant Sci. 2016, 7, 1865. [CrossRef]

49. Jalaiah, M.; Sarvanan, R.; Gowtham, C.H.; Vinay, Y.; Akhila, Y. Evaluation of Cardioprotective Activity of Allium cepa Aerial Leaves. Int. J. Curr. Pharm. Res. 2017, 9, 27. [CrossRef]

50. Štajner, D.; Milić, N.; Čanadanović-Brunet, J.; Kapor, A.; Štajner, M.; Popović, B.M. Exploring Allium species as a source of potential medicinal agents. Phytother. Res. 2006, 20, 581-584. [CrossRef]

51. Wilson, A.; Pandya, D.; Solanki, D.H. Comparative Phytochemical Screening of Leaves and Bulb of Allium sativum L. Int. J. Inf. Comput. Sci. 2019, 6, 5 .

52. Fukaya, M.; Nakamura, S.; Hayashida, H.; Noguchi, D.; Nakashima, S.; Yoneda, T.; Matsuda, H. Structures of Cyclic Organosulfur Compounds From Garlic (Allium sativum L.) Leaves. Front. Chem. 2020, 8, 282. [CrossRef] [PubMed]

53. Meshram, G.A.; Khamkar, S.S. Effect Of Oleanolic Acid Isolated From Garlic Leaves On Carbohydrate Metabolizing Enzymes, In Vitro. Int. J. Pharm. Sci. Res. 2014, 5, 988-991.

54. Pan, Y.; Zheng, Y.M.; Ho, W.S. Effect of quercetin glucosides from Allium extracts on HepG2, PC-3 and HT-29 cancer cell lines. Oncol. Lett. 2018, 15, 4657-4661. [CrossRef]

55. Yoshimoto, N.; Yabe, A.; Sugino, Y.; Murakami, S.; Sai-ngam, N.; Sumi, S.; Tsuneyoshi, T.; Saito, K. Garlic $\hat{\mathrm{I}}^{3}$-glutamyl transpeptidases that catalyze deglutamylation of biosynthetic intermediate of alliin. Front. Plant Sci. 2015, 5, 1-11. [CrossRef]

56. Yoshimoto, N.; Onuma, M.; Mizuno, S.; Sugino, Y.; Nakabayashi, R.; Imai, S.; Tsuneyoshi, T.; Sumi, S.; Saito, K. Identification of a flavin-containing $S$-oxygenating monooxygenase involved in alliin biosynthesis in garlic. Plant J. 2015, 83, 941-951. [CrossRef]

57. Kim, M.-Y.; Kim, Y.-C.; Chung, S.-K. Identification andin vitro biological activities of flavonols in garlic leaf and shoot: Inhibition of soybean lipoxygenase and hyaluronidase activities and scavenging of free radicals. J. Sci. Food Agric. 2005, 85, 633-640. [CrossRef]

58. Fukaya, M.; Nakamura, S.; Nakagawa, R.; Kinka, M.; Nakashima, S.; Matsuda, H. Cyclic sulfur-containing compounds from Allium fistulosum 'Kujou'. J. Nat. Med. 2019, 73, 397-403. [CrossRef]

59. Ajayi, G.O.; Akinsanya, M.A.; Agbabiaka, A.T.; Oyebanjo, K.S.; Hungbo, T.D.; Olagunju, J.A. D-Limonene: A major bioactive constituent in Allium fistulosum identified by GC-MS analysis. J. Phytopharm. 2019, 8, 257-259. [CrossRef]

60. Nohara, T.; Fujiwara, Y.; Kudo, R.; Yamaguchi, K.; Ikeda, T.; Murakami, K.; Ono, M.; Kajimoto, T.; Takeya, M. Isolation and Characterization of New Onionins $\mathrm{A}_{2}$ and $\mathrm{A}_{3}$ from Allium cepa, and of Onionins $\mathrm{A}_{1}, \mathrm{~A}_{2}$, and $\mathrm{A}_{3}$ from Allium fistulosum. Chem. Pharm. Bull. 2014, 62, 1141-1145. [CrossRef]

61. El-Hadidy, E.M.; Mossa, M.E.A.; Habashy, H.N. Effect of freezing on the pungency and antioxidants activity in leaves and bulbs of green onion in Giza 6 and Photon varieties. Ann. Agric. Sci. 2014, 59, 33-39. [CrossRef]

62. Domínguez, O.G.P.; Pesantes, K.E.B.; Martínez, M.M.; Gaitén, Y.G. Estudio químico y evaluación biológica del extracto etanólico de Allium schoenoprasum L. Regel \& Tiling (Cebollín). Rev. Cuba. Farm. 2019, 52, 13.

63. Díaz, A.B.; Vera, J.R.; Fermín, L.R.; Méndez, A.M.; Zambrano, R.A.; Contreras, L.R. Composition of the essential oil of leaves and roots of Allium schoenoprasum L. (Alliaceae). Boletín Latinoam. Caribe Plantas Med. Aromáticas 2011, 10, $218-221$.

64. Parvu, A.E.; Parvu, M.; Vlase, L.; Miclea, P.; Mot, A.C.; Silaghi-Dumitrescu, R. Anti-inflammatory Effects of Allium schoenoprasum L. Leaves. J. Physiol. Pharmacol. 2014, 65, 309-315.

65. Beretta, H.V.; Bannoud, F.; Insani, M.; Berli, F.; Hirschegger, P.; Galmarini, C.R.; Cavagnaro, P.F. Relationships between bioactive compound content and the antiplatelet and antioxidant activities of six Allium vegetable species. Food Technol. Biotechnol. 2017, 55, 266-275. [CrossRef]

66. Fukaya, M.; Nakamura, S.; Kyoku, Y.; Nakashima, S.; Yoneda, T.; Matsuda, H. Cyclic sulfur metabolites from Allium schoenoprasum var. foliosum. Phytochem. Lett. 2019, 29, 125-128. [CrossRef]

67. Shirshova, T.I.; Beshlei, I.V.; Deryagina, V.P.; Ryzhova, N.I.; Matistov, N.V. Chemical composition of Allium schoenoprasum leaves and inhibitory effect of their extract on tumor growth in mice. Pharm. Chem. J. 2013, 46, 672-675. [CrossRef]

68. Petkova, N.T.; Ivanov, I.G.; Raeva, M.; Topuzova, M.G.; Todorova, M.M.; Denev, P.P. Fructans and antioxidants in leaves of culinary herbs from Asteraceae and Amaryllidaceae families. Food Res. 2019, 3, 407-415. [CrossRef]

69. Barla, G.-F.; Seritan, M.P.; Sanduleac, E.; Ciornei, S.E. Antioxidant Activity and Total Phenolic Content in Allium ursinum and Ranunculus ficaria. Food Environ. Saf. 2014, 8, 349-353. [CrossRef] 
70. Sahnoun, D.; Ksouri, W.M.; Younes, I.; Hammami, M.; Bettaieb, I.; Saada, M.; Mkadmini, K.; Ksouri, R.; Serairi, R.B. Antioxidant activity and biochemical composition of fresh bulbs and leaves of wild garlic Allium ursinum. J. New Sci. 2017, 44, 8.

71. Oszmiański, J.; Kolniak-Ostek, J.; Wojdyło, A. Characterization and Content of Flavonol Derivatives of Allium ursinum L. Plant. J. Agric. Food Chem. 2013, 61, 176-184. [CrossRef] [PubMed]

72. Ivanova, A.; Mikhova, B.; Najdenski, H.; Tsvetkova, I.; Kostova, I. Chemical Composition and Antimicrobial Activity of Wild Garlic Allium ursinum of Bulgarian Origin. Nat. Prod. Commun. 2009, 4, 1934578X0900400. [CrossRef]

73. Sebtosheikh, P.; Qomi, M.; Ghadami, S.; Mojab, F. Analysis of essential oil from leaves and Bulb of Allium atroviolaceum. Int. Pharm. Acta 2020, 3, 1-6. [CrossRef]

74. Lorigooini, Z.; Ayatollahi, S.A.; Amidi, S.; Kobarfard, F. Evaluation of Anti-Platelet Aggregation Effect of Some Allium Species. Iran. J. Pharm. Res. 2015, 14, 1225.

75. Ye, C.-L.; Dai, D.-H.; Hu, W.-L. Antimicrobial and antioxidant activities of the essential oil from onion (Allium cepa L.). Food Control 2013, 30, 48-53. [CrossRef]

76. Parmar, P.; Salman, A.; Kalavathy, C.M.; Jesudasan, C.N.; Thomas, P.A. Pneumococcal keratitis: A clinical profile. Clin. Experiment. Ophthalmol. 2003, 31, 44-47. [CrossRef]

77. Shouval, D.S.; Greenberg, D.; Givon-Lavi, N.; Porat, N.; Dagan, R. Site-Specific Disease Potential of Individual Streptococcus pneumoniae Serotypes in Pediatric Invasive Disease, Acute Otitis Media and Acute Conjunctivitis. Pediatric Infect. Dis. J. 2006, 25, 602-607. [CrossRef]

78. Ying, Q. Antimicrobial resistance, serotypes and genotypes of Streptococcus pneumoniae isolates associated with ocular infection in China. Afr. J. Microbiol. Res. 2012, 6, 160-164. [CrossRef]

79. Roopa, V.M.; Suvarna, V.C.; Natesh, N. Original Research Article Antimicrobial activity of plant extracts against post harvest spoilage of onions. Int. J. Curr. Microbiol. App. Sci. 2014, 3, 388-394.

80. Sulaiman, A.F.; Alwan, W.M.; Salman, S.A.; Al-Abodi, E.E. A Comparative Study of Chemical Compounds and Anti-Bacterial Efficacy of Different Allium cepa Plant Extracts. Syst. Rev. Pharm. 2021, 12, 4.

81. Stankov, S.V. Definition of Inflammation, Causes of Inflammation and Possible Anti-inflammatory Strategies. Open Inflamm. J. 2012, 5, 1-9. [CrossRef]

82. Marefati, N.; Ghorani, V.; Shakeri, F.; Boskabady, M.; Kianian, F.; Rezaee, R.; Boskabady, M.H. A review of anti-inflammatory, antioxidant, and immunomodulatory effects of Allium cepa and its main constituents. Pharm. Biol. 2021, 59, 287-302. [CrossRef]

83. Arreola, R.; Quintero-Fabián, S.; López-Roa, R.I.; Flores-Gutiérrez, E.O.; Reyes-Grajeda, J.P.; Carrera-Quintanar, L.; Ortuño-Sahagún, D. Immunomodulation and Anti-Inflammatory Effects of Garlic Compounds. J. Immunol. Res. 2015, 2015, 1-13. [CrossRef]

84. Aslam, Z.; Akhtar, S.; Imran, M.; Nadeem, M.; Gilani, S.A.; Elnashar, M.; El-ghorab, A. Antioxidant Activity, Anti-Inflammatory Activities, Anti-Cancer and Chemical Composition of Spring Onion (Allium fistolisum) Extracts. Res. J. Pharm. Biol. Chem. Sci. 2017, 8, 1880-1890.

85. Lesjak, M.; Beara, I.; Simin, N.; Pintać, D.; Majkić, T.; Bekvalac, K.; Orčić, D.; Mimica-Dukić, N. Antioxidant and anti-inflammatory activities of quercetin and its derivatives. J. Funct. Foods 2018, 40, 68-75. [CrossRef]

86. Shang, A.; Cao, S.-Y.; Xu, X.-Y.; Gan, R.-Y.; Tang, G.-Y.; Corke, H.; Mavumengwana, V.; Li, H.-B. Bioactive Compounds and Biological Functions of Garlic (Allium sativum L.). Foods 2019, 8, 246. [CrossRef]

87. Wang, B.-S.; Huang, G.-J.; Lu, Y.-H.; Chang, L.-W. Anti-inflammatory effects of an aqueous extract of Welsh onion green leaves in mice. Food Chem. 2013, 138, 751-756. [CrossRef]

88. Pan, S.; Aparna, L.I.; Priyanka, P. Anti-inflammatory activity of aqueous extract of Allium satium Leaves. Asian J. Pharm. Clin. Res. 2015, 8, 78-80.

89. Sinha, T. Tumors: Benign and Malignant. Cancer Ther. Oncol. Int. J. 2018, 10, 1-3. [CrossRef]

90. Nohara, T.; Fujiwara, Y. Antitumor Sulfur Compounds from Allium Species (Onion, Welsh Onion, and Garlic). Nat. Prod. Commun. 2017, 12, 1934578X1701200. [CrossRef]

91. Twomey, L.; Wallace, R.G.; Cummins, P.M.; Degryse, B.; Sheridan, S.; Harrison, M.; Moyna, N.; Meade-Murphy, G.; Navasiolava, N.; Custaud, M.-A.; et al. Platelets: From Formation to Function. In Homeostasis-An Integrated Vision; Lasakosvitsch, F., Dos Anjos Garnes, S., Eds.; IntechOpen: London, UK, 2019; ISBN 978-1-78985-077-2.

92. Clemetson, K.J. Platelets and Primary Haemostasis. Thromb. Res. 2012, 129, 220-224. [CrossRef]

93. Younis, L.S.; Mohammed, I.M.; Najah, H.T.; Haider, A.M. Antiplatelet drugs overview. GSC Biol. Pharm. Sci. 2020, 10, 81-89. [CrossRef]

94. Saplonţai-Pop, A.; Moţ, A.; Moldovan, M.; Oprean, R.; Silaghi-Dumitrescu, R.; Orășan, O.; Pârvu, M.; Gal, E.; Ionescu, C. Testing antiplatelet and antioxidant activity of the extract of seven varieties of Allium cepa L. Open Life Sci. 2015, 10, 89-98. [CrossRef]

95. Ko, E.Y.; Nile, S.H.; Jung, Y.-S.; Keum, Y.S. Antioxidant and antiplatelet potential of different methanol fractions and flavonols extracted from onion (Allium cepa L.). 3 Biotech 2018, 8, 155. [CrossRef]

96. Gong, L.; Feng, D.; Wang, T.; Ren, Y.; Liu, Y.; Wang, J. Inhibitors of $\alpha$-amylase and $\alpha$-glucosidase: Potential linkage for whole cereal foods on prevention of hyperglycemia. Food Sci. Nutr. 2020, 8, 6320-6337. [CrossRef] [PubMed]

97. Da Silva, V.C.P.; Bettoni, M.M.; Bona, C.; Foerster, L.A. Morphological and chemical characteristics of onion plants (Allium cepa L.) associated with resistance to onion thrips. Acta Sci. Agron. 2014, 37, 85. [CrossRef] 
98. Tiwari, S.; Srivastava, R.; Singh, C.; Shukla, K.; Singh, R.; Singh, P.; Singh, R.; Singh, N.; Sharma, R. Amylases: An Overview with Special Reference to Alpha Amylase. J. Glob. Biosci. 2015, 4, 1886-1901.

99. Williams, J.A. Amylase. Pancreapedia 2017, 1-8. [CrossRef]

100. Adefisoye, S.A.; Sakariyau, A.O. Production of Glucoamylase by Aspergillus niger in Solid State Fermentation. Adv. Biol. Res. 2018, 2,7-11. [CrossRef]

101. Miller, G.L. Use of Dinitrosalicylic Acid Reagent for Determination of Reducing Sugar. Anal. Chem. 1959, 31, 426-428. [CrossRef]

102. Singh, V.; Kumar, R. Study of Phytochemical Analysis and Antioxidant Activity of Allium sativum of Bundelkhand Region. Int. J. Life Sci. Sci. Res. 2017, 3, 1451-1458. [CrossRef]

103. Shakurfow, F.A.A.; Buazzi, M.M.; Gamal, M.A.B. Assessment of antimicrobial activity of onion (Allium cepa) and garlic (Allium sativum) extracts on Listeria monocytogenes; in vitro study. Lebda Med. J. 2015, 1, 1-5.

104. Khalid, N.; Ahmed, I.; Latif, M.S.Z.; Rafique, T.; Fawad, S.A. Comparison of antimicrobial activity, phytochemical profile and minerals composition of garlic Allium sativum and Allium tuberosum. J. Korean Soc. Appl. Biol. Chem. 2014, 57, 311-317. [CrossRef]

105. Popova, A.; Mihaylova, D.; Alexieva, I. GC-MS chemical composition of volatile oil and mineral element content of Allium ursinum and Nectaroscordum siculum. Pak. J. Bot. 2018, 50, 2351-2354.

106. Elsayed Azab, A.; Adwas, A.A.; Ibrahim Elsayed, A.S.; Quwaydir, F.A. Oxidative stress and antioxidant mechanisms in human body. J. Appl. Biotechnol. Bioeng. 2019, 6, 43-47. [CrossRef]

107. Hunyadi, A. The mechanism(s) of action of antioxidants: From scavenging reactive oxygen/nitrogen species to redox signaling and the generation of bioactive secondary metabolites. Med. Res. Rev. 2019, 39, 2505-2533. [CrossRef]

108. Lü, J.-M.; Lin, P.H.; Yao, Q.; Chen, C. Chemical and molecular mechanisms of antioxidants: Experimental approaches and model systems. J. Cell. Mol. Med. 2010, 14, 840-860. [CrossRef]

109. Nimse, S.B.; Pal, D. Free radicals, natural antioxidants, and their reaction mechanisms. RSC Adv. 2015, 5, 27986-28006. [CrossRef]

110. Sunitha, D. A review on antioxidant methods. Asian J. Pharm. Clin. Res. 2016, 9, 14-32. [CrossRef]

111. Azat Aziz, M.; Shehab Diab, A.; Abdulrazak Mohammed, A. Antioxidant Categories and Mode of Action. In Antioxidants; Shalaby, E., Ed.; IntechOpen: London, UK, 2019; ISBN 978-1-78923-919-5.

112. Alam, M.N.; Bristi, N.J.; Rafiquzzaman, M. Review on in vivo and in vitro methods evaluation of antioxidant activity. Saudi Pharm. J. 2013, 21, 143-152. [CrossRef]

113. Apak, R.; Özyürek, M.; Güçlü, K.; Çapanoğlu, E. Antioxidant Activity/Capacity Measurement. 1. Classification, Physicochemical Principles, Mechanisms, and Electron Transfer (ET)-Based Assays. J. Agric. Food Chem. 2016, 64, 997-1027. [CrossRef]

114. Nencini, C.; Cavallo, F.; Capasso, A.; Franchi, G.G.; Giorgio, G.; Micheli, L. Evaluation of antioxidative properties of Allium species growing wild in Italy. Phytother. Res. 2007, 21, 874-878. [CrossRef]

115. Kruzlicova, D.; Danihelova, M.; Veverka, M. Quantitative Structure-Antioxidant Activity Relationship of Quercetin and its New Synthetised Derivatives. Nova Biotechnol. Chim. 2012, 11, 37-44. [CrossRef]

116. Tong, W.; Welsh, W.J.; Shi, L.; Fang, H.; Perkins, R. Structure-activity relationship approaches and applications. Environ. Toxicol. Chem. 2003, 22, 1680. [CrossRef]

117. Yao, Y.; Lin, G.; Xie, Y.; Ma, P.; Li, G.; Meng, Q.; Wu, T. Preformulation studies of myricetin: A natural antioxidant flavonoid. Pharmazie 2014, 69, 19-26. [CrossRef]

118. Sim, G.-S.; Lee, B.-C.; Cho, H.S.; Lee, J.W.; Kim, J.-H.; Lee, D.-H.; Kim, J.-H.; Pyo, H.-B.; Moon, D.C.; Oh, K.-W.; et al. Structure activity relationship of antioxidative property of flavonoids and inhibitory effect on matrix metalloproteinase activity in UVAirradiated human dermal fibroblast. Arch. Pharm. Res. 2007, 30, 290-298. [CrossRef]

119. Bilyk, A.; Cooper, P.L.; Sapers, G.M. Varietal differences in distribution of quercetin and kaempferol in onion (Allium cepa L.) tissue. J. Agric. Food Chem. 1984, 32, 274-276. [CrossRef]

120. Seyoum, A.; Asres, K.; El-Fiky, F.K. Structure-radical scavenging activity relationships of flavonoids. Phytochemistry 2006, 67, 2058-2070. [CrossRef]

121. Zhang, Y.; Wang, D.; Yang, L.; Zhou, D.; Zhang, J. Purification and Characterization of Flavonoids from the Leaves of Zanthoxylum bungeanum and Correlation between Their Structure and Antioxidant Activity. PLoS ONE 2014, 9, e105725. [CrossRef] [PubMed]

122. Rice-Evans, C.A.; Miller, N.J.; Paganga, G. Antioxidant properties of phenolic compounds. Trends Plant Sci. 1997, 2, 152-159. [CrossRef]

123. Ahmadi, S.M.; Farhoosh, R.; Sharif, A.; Rezaie, M. Structure-Antioxidant Activity Relationships of Luteolin and Catechin. J. Food Sci. 2020, 85, 298-305. [CrossRef]

124. Rice-Evans, C.A.; Miller, N.J.; Paganga, G. Structure-antioxidant activity relationships of flavonoids and phenolic acids. Free Radic. Biol. Med. 1996, 20, 933-956. [CrossRef]

125. Tu, B.; Liu, Z.J.; Chen, Z.F.; Ouyang, Y.; Hu, Y.J. Understanding the structure-activity relationship between quercetin and naringenin: In vitro. RSC Adv. 2015, 5, 106171-106181. [CrossRef]

126. Aoyama, S.; Yukiko, Y. Antioxidant Activity and Flavonoid Content of Welsh Onion (Allium fistulosum) and the Effect of Thermal Treatment. Food Sci. Technol. Res. 2007, 13, 67-72. [CrossRef]

127. Li, K.; Fan, H.; Yin, P.; Yang, L.; Xue, Q.; Li, X.; Sun, L.; Liu, Y. Structure-activity relationship of eight high content flavonoids analyzed with a preliminary assign-score method and their contribution to antioxidant ability of flavonoids-rich extract from Scutellaria baicalensis shoots. Arab. J. Chem. 2018, 11, 159-170. [CrossRef] 
128. Farkas, O.; Jakus, J.; Héberger, K. Quantitative Structure-Antioxidant Activity Relationships of Flavonoid Compounds. Molecules 2004, 9, 1079-1088. [CrossRef] [PubMed]

129. Sharma, N.; Biswas, S.; Dayan, N.A.; Sarwat, M. Antioxidant Role of Kaempferol in the Management of Hepatocellular Carcinoma. Med. Pharmacol. 2021. [CrossRef]

130. Hofer, S.; Geisler, S.; Lisandrelli, R.; Nguyen Ngoc, H.; Ganzera, M.; Schennach, H.; Fuchs, D.; Fuchs, J.E.; Gostner, J.M.; Kurz, K. Pharmacological Targets of Kaempferol Within Inflammatory Pathways-A Hint Towards the Central Role of Tryptophan Metabolism. Antioxidants 2020, 9, 180. [CrossRef]

131. Sordon, S.; Popłoński, J.; Milczarek, M.; Stachowicz, M.; Tronina, T.; Kucharska, A.Z.; Wietrzyk, J.; Huszcza, E. StructureAntioxidant-Antiproliferative Activity Relationships of Natural C7 and C7-C8 Hydroxylated Flavones and Flavanones. Antioxidants 2019, 8, 210. [CrossRef]

132. Zheng, Y.-Z.; Deng, G.; Guo, R.; Chen, D.-F.; Fu, Z.-M. DFT Studies on the Antioxidant Activity of Naringenin and Its Derivatives: Effects of the Substituents at C3. Int. J. Mol. Sci. 2019, 20, 1450. [CrossRef]

133. Silva dos Santos, J.; Gonçalves Cirino, J.P.; de Oliveira Carvalho, P.; Ortega, M.M. The Pharmacological Action of Kaempferol in Central Nervous System Diseases: A Review. Front. Pharmacol. 2021, 11, 565700. [CrossRef]

134. Silva, M.M.; Santos, M.R.; Caroço, G.; Rocha, R.; Justino, G.; Mira, L. Structure-antioxidant Activity Relationships of Flavonoids: A Re-examination. Free Radic. Res. 2002, 36, 1219-1227. [CrossRef]

135. Simos, Y.V.; Verginadis, I.I.; Toliopoulos, I.K.; Velalopoulou, A.P.; Karagounis, I.V.; Karkabounas, S.C.; Evangelou, A.M. Effects of catechin and epicatechin on superoxide dismutase and glutathione peroxidase activity, in vivo. Redox Rep. 2012, 17, 181-186. [CrossRef]

136. Bajerska, J.; Mildner-Szkudlarz, S.; Jeszka, J.; Szwengiel, A. Catechin stability, antioxidant properties and sensory profiles of rye breads fortified with green tea extracts. J. Food Nutr. Res. 2010, 49, 104-111.

137. Xu, D.; Hu, M.-J.; Wang, Y.-Q.; Cui, Y.-L. Antioxidant Activities of Quercetin and Its Complexes for Medicinal Application. Molecules 2019, 24, 1123. [CrossRef]

138. Van Acker, S.A.B.E.; de Groot, M.J.; van den Berg, D.-J.; Tromp, M.N.J.L.; Donné-Op den Kelder, G.; van der Vijgh, W.J.F.; Bast, A. A Quantum Chemical Explanation of the Antioxidant Activity of Flavonoids. Chem. Res. Toxicol. 1996, 9, 1305-1312. [CrossRef]

139. Lakhanpal, P.; Rai, D.K. Quercetin: A Versatile Flavonoid. Internet J. Med. Update Ejournal 2007, 2, 22-37. [CrossRef]

140. Batiha, G.E.-S.; Beshbishy, A.M.; Ikram, M.; Mulla, Z.S.; El-Hack, M.E.A.; Taha, A.E.; Algammal, A.M.; Elewa, Y.H.A. The Pharmacological Activity, Biochemical Properties, and Pharmacokinetics of the Major Natural Polyphenolic Flavonoid: Quercetin. Foods 2020, 9, 374. [CrossRef]

141. Li, X.; Jiang, Q.; Wang, T.; Liu, J.; Chen, D. Comparison of the Antioxidant Effects of Quercitrin and Isoquercitrin: Understanding the Role of the 6"-OH Group. Molecules 2016, 21, 1246. [CrossRef]

142. Vásquez-Espinal, A.; Yañez, O.; Osorio, E.; Areche, C.; García-Beltrán, O.; Ruiz, L.M.; Cassels, B.K.; Tiznado, W. Theoretical Study of the Antioxidant Activity of Quercetin Oxidation Products. Front. Chem. 2019, 7, 818. [CrossRef]

143. Heim, K.E.; Tagliaferro, A.R.; Bobilya, D.J. Flavonoid antioxidants: Chemistry, metabolism and structure-activity relationships. J. Nutr. Biochem. 2002, 13, 572-584. [CrossRef]

144. Xiao, Z.; He, L.; Hou, X.; Wei, J.; Ma, X.; Gao, Z.; Yuan, Y.; Xiao, J.; Li, P.; Yue, T. Relationships between Structure and Antioxidant Capacity and Activity of Glycosylated Flavonols. Foods 2021, 10, 849. [CrossRef]

145. Lien, E.J.; Ren, S.; Bui, H.-H.; Wang, R. Quantitative structure-activity relationship analysis of phenolic antioxidants. Free Radic. Biol. Med. 1999, 26, 285-294. [CrossRef] 